\title{
Suspended sediment transport in the Gulf of Lions (NW Mediterranean): Impact of extreme storms and floods
}

\author{
C. Ulses ${ }^{\mathrm{a}, \mathrm{b}, *}$, C. Estournel ${ }^{\mathrm{a}}$, X. Durrieu de Madron $^{\mathrm{c}}$, A. Palanques ${ }^{\mathrm{d}}$ \\ ${ }^{a}$ Pole d'Océanographie Côtière, Laboratoire d'Aérologie-CNRS-Université de Toulouse, 14 avenue E. Belin, 31400 Toulouse, France \\ ${ }^{\mathrm{b}}$ Centre for Estuarine and Marine Ecology, Netherlands Institute of Ecology, P.O. Box 140, 4400 AC Yerseke, The Netherlands \\ ${ }^{\mathrm{c}}$ Centre de Formation et de Recherche sur l'Environnement Marin - CNRS-Université de Perpignan, France \\ ${ }^{\mathrm{d}}$ Institut de Ciències del Mar (CSIC), Passeig Maritim de la Barceloneta, 37-49, E-08003 Barcelona, Spain
}

\begin{abstract}
In situ observations were combined with 3D modeling to gain understanding of and to quantify the suspended sediment transport in the Gulf of Lions (NW Mediterranean Sea). The outputs of a hydrodynamic-sediment transport coupled model were compared to nearbottom current and suspended sediment concentration measurements collected at the head of seven submarine canyons and at a shallow shelf site, over a 6-month period (November 2003-May 2004). The comparisons provide a reasonable validation of the model that reproduces the observed spatial and time variations. The study period was marked by an unusual occurrence of marine storms and high river inputs. The major water and sediment discharges were supplied by the Rhone, the largest Mediterranean river, during an exceptional flood accompanying a severe marine storm in early December 2003. A second major storm, with moderate flooding, occurred in February 2004. The estimate of river input during the studied period was $5.9 \mathrm{Mt}$. Our study reveals (i) that most of the particulate matter delivered by the Rhone was entrapped on the prodelta, and (ii) that marine storms played a crucial role on the sediment dispersal on the shelf and the off-shelf export. The marine storms occurring in early December 2003 and late February 2004 resuspended a very large amount of shelf sediment $(>8 \mathrm{Mt}$ ). Erosion was controlled by waves on the inner shelf and by energetic currents on the outer shelf. Sediment deposition took place in the middle part of the shelf, between 50 and $100 \mathrm{~m}$ depth. Resuspended sediments and river-borne particles were transported to the southwestern end of the shelf by a cyclonic circulation induced by these onshore winds and exported towards the Catalan shelf and into the Cap de Creus Canyon which incises the slope close to the shore. Export taking place mostly during marine storms was estimated to reach $9.1 \mathrm{Mt}$ during the study period.
\end{abstract}

Keywords: Sediment transport; Sediment resuspension; Sediment budget; 3D sediment transport modeling; Continental margins; Northwestern Mediterranean Sea; Gulf of Lions

\section{Introduction}

Continental margins, which receive large amounts of particulate matter related to the erosion of continents, generally represent regions of massive deposition but are also a sediment source for the deep basins. Sediment transport, seabed reworking and off-shelf export on continental margins are considered to be primarily driven

\footnotetext{
${ }^{*}$ Corresponding author at: Centre for Estuarine and Marine Ecology, Netherlands Institute of Ecology, P.O. Box 140, 4400 AC Yerseke, The Netherlands. Tel.: +31113577472 .

E-mail address: c.ulses@nioo.knaw.nl (C. Ulses).
}

by episodic, high energy events, among which floods, storms and associated swell, and strong wind-driven currents are the most common examples. These extreme events that control the inputs, resuspension, sediment transport pathways and depositional sites, are considered to strongly affect the sediment budget and the formation of strata (Parsons and Nittrouer, 2007). Besides the formation and preservation of event beds in sediment deposits, these events also affect the amount of sediment that escapes the shelf break (e.g., Sommerfield and Nittrouer, 1999). The net off-shelf sediment fluxes are usually quantified as a residual value in sediment budgets, which are generally based on sediment core dating and river inputs. They 
generally represent a "mean" export averaged over a secular time scale (typically 100-year for ${ }^{210} \mathrm{~Pb}$-based accumulation rates). Moored instruments (sediment traps, currentmeters, turbidimeter) describe the temporal variability of sediment fluxes escaping the shelf at shorter time scales (from hours to months) but generally lack the spatial coverage to estimate the export linked to significant events. The study of the impact of energetic sediment transport processes on bed modifications caused by sediment erosion or deposit and sediment budgets at the shelf scale therefore requires the coupling of a field study with a modeling study.

Within the framework of the EUROSTRATAFORM program (Weaver et al., 2006), the impact of episodic, high energy events on the sediment dynamics and budget was investigated on two Mediterranean margins - the Adriatic Sea and the Gulf of Lions. Despite their distinct shelf morphology, these margins have relatively analogous river discharges, originating both from one large river and smaller rivers, and hydrodynamical forcings. Recent studies in the Gulf of Lions identified the role of waves and currents driven by onshore and off-shore wind regimes as dominant mechanisms for the dispersal of river plumes, resuspension of shelf sediment, and off-shelf sediment export (e.g., Estournel et al., 1997; Ferré et al., 2005; Canals et al., 2006; Guillén et al., 2006; Heussner et al., 2006; Palanques et al., 2006). Secular accumulation rates and grain-size patterns reveal distinct sedimentary facies on the shelf, including prodeltaic and mid-shelf depocenters of fine sediments. A sediment budget suggests that most (ca. $90 \%$ ) of the river sediment discharge is trapped on the shelf (Durrieu de Madron et al., 2000). However, because of the spatial limitation of measurements, the pathways of riverine and resuspended sediment, the limits of deposition/ accumulation patterns on the shelf, and the off-shelf export of sediment during extreme events (flood, storms) are still poorly understood.

Three-dimensional sediment transport models are useful tools to study the fate of river-borne and resuspended sediment of the shelf as well as the transport to the open sea. We combined a 3D sediment transport model with extensive field measurements performed in the Gulf of Lions during a 6-month period (autumn 2003 and winter 2004) characterized by extreme flood and marine storm events. In the present work, we took advantage of previous works by Ulses et al. (2008) who validated the hydrodynamic model and described the physical mechanisms controlling the spatial and temporal variability of the shelf to slope transfer of water, and Palanques et al. (2006) who measured the suspended particulate matter transport, during the study period. The present paper aims at determining (i) the fate of river sediment inputs, (ii) the relative role of wave and wind-driven flows for the reworking and transport of sediment on the shelf, (iii) the amount of sediment escaping the shelf break, (iv) the role of canyons as effective conduits for the offshelf transport, and (v) the contribution of extreme flood and storms that occurred during the study period.

\section{Regional setting}

The Gulf of Lions is located in the northwestern Mediterranean. The crescent-shape continental shelf is bounded at its northeastern and southwestern ends by promontories where the shelf almost vanishes. The continental slope is incised by an intricate network of submarine canyons (Fig. 1).

The grain size distribution of superficial bottom sediments is shown in Fig. 1. Sands of the inner shelf broadly display a seaward-fining texture and merge, in water deeper than 20-30 m, with mid-shelf muds, except on the Rhone River submarine delta where a large accumulation of silty muds is located closer to the coast. Sediment gets progressively coarser across the outer shelf. Sandy sediments and even shells are found around the shelf edge and in canyon heads.

\subsection{Rivers}

Fresh water and sediment inputs to the Gulf originate mainly from the Rhone River although about nine small rivers occasionally may deliver substantial amount of fresh water and sediment (Fig. 1). The major river discharge occurs mostly during flooding events, preferentially in spring and fall, and reveals a strong interannual variability. Thus, annual river inputs of sediment vary within one order of magnitude from 2.4 to $25 \mathrm{Mt} \mathrm{yr}^{-1}$, with an average long-term mean of $8.5 \mathrm{Mt} \mathrm{yr}^{-1}$ (1980-1999 period, Ludwig et al., 2003).

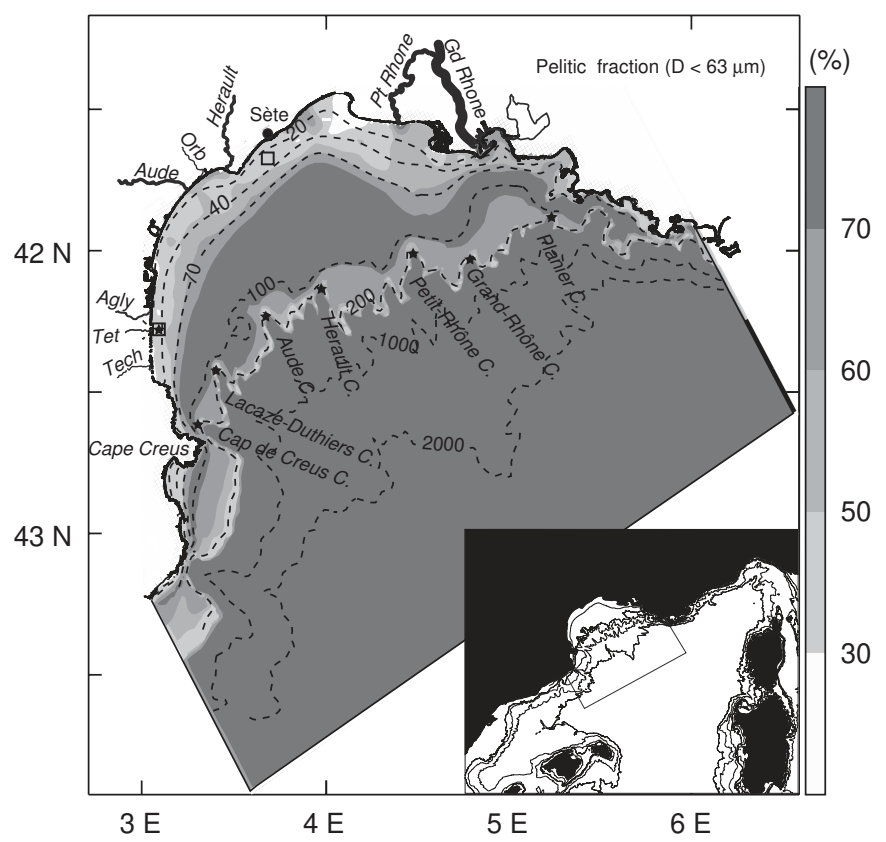

Fig. 1. Map of the Gulf of Lions, showing the bathymetry (m), the fraction of mud (clay and silt) in the sediment bed and the position of the different instruments moored in the canyon heads and on the inner shelf (stars) and the wave gauges (squares). The inset delineates the domain of the Gulf of Lions model in the northwestern Mediterranean. 


\subsection{Wind-wave regimes}

Strong winds over the Gulf of Lions are frequent and produce distinctive wave regimes. The orography controls the direction of the continental winds, which blow from the north (Mistral) and northwest (Tramontane). Due to a reduced fetch, these winds generate small waves (significant wave height $<2 \mathrm{~m}$, peak period $<6 \mathrm{~s}$ ) on the shelf. Conversely, eastern to southeastern winds are episodic and short-lived, and are associated with long fetch and large swells (significant wave height up to $10 \mathrm{~m}$, peak period up to $12 \mathrm{~s}$ ). These marine wind episodes are often accompanied by river floods as the transport of humid marine air over coastal relief induces abundant precipitation. Sediment resuspension results primarily from the effect of southeasterly swells associated with marine winds (Ferré et al., 2005; Guillén et al., 2006).

\subsection{Circulation patterns}

The predominant north to northwestern winds induce distinctive circulation cells on the shelf, favoring intrusions of slope waters into the eastern and central parts, and export of shelf water at the southwestern end of the Gulf (Estournel et al., 2003; Petrenko et al., 2005; Ulses et al., 2008). Furthermore these cold and dry continental winds are responsible for the cooling and homogenization of the shelf water column during winter, which could generate dense water. Dense water plumes spread over the western part of the shelf and finally escape at its southwestern end (Dufau-Julliand et al., 2004; Ulses et al., 2008). Eastern to southeastern marine winds induce a sea level rise at the shore and an overall intense cyclonic circulation on the shelf (Ulses et al., 2008).

A permanent cyclonic current (the Northern Current) flows along the slope and is part of the general circulation of the western Mediterranean basin. It forms a density front that separates the low-salinity shelf water from the more saline open sea water, limiting the off-shelf dispersal while enhancing along-slope dispersal (Durrieu de Madron et al., 1990; Lapouyade and Durrieu de Madron, 2001). Hence, constrained by the slope current offshore and the coast inshore, most shelf water is funneled towards the narrowing southwestern shelf end where it impinges on the Cap de Creus promontory and is thereby deviated towards the nearby canyons.

Various experimental studies showed that canyons act as preferential conduits, with respect to the adjacent open slope, for the particulate matter exported from the shelf to the slope (Monaco et al., 1990; Durrieu de Madron et al., 1990; Monaco et al., 1999). Continuous observations since 1993 of near-bottom particle fluxes at $1000 \mathrm{~m}$ depth in the Lacaze-Duthiers and Planier Canyons (respectively at the southwestern and northeastern ends of the Gulf) have emphasized the role of dense water cascading, but have not been able to estimate the role of marine storms on the space and time variability of shelf-slope exchanges, because of the sampling intervals and the distance and depth from the shelf edge (Heussner et al., 2006).

\section{Material and methods}

\subsection{The numerical model}

The modeling is based on a coupling between a 3D coastal circulation model, a wave model and a sediment transport model. Simulations with the hydrodynamic model and the wave model were independently performed, storing the current and the turbulent diffusion coefficient, and the wave parameters, respectively. Then the sediment transport model was run using the circulation and wave model results as forcing functions. The three sub-models are described in the following sections.

\subsubsection{The coastal circulation ocean model}

The coastal circulation ocean model SYMPHONIE is a $3 \mathrm{D}$ primitive equation hydrostatic model that has been described by Marsaleix et al. (2008). The turbulence closure scheme is based on a prognostic equation for the turbulent kinetic energy and on a diagnostic equation for the mixing and dissipation length scales (Bougeault and Lacarrère, 1989). A time-splitting technique (Blumberg and Mellor, 1987) allows the vertical shear of the current and the depthaveraged horizontal components to be computed separately with appropriate time steps. The modeling of the study period (October 2003-May 2004) was previously validated and used to investigate the physical mechanisms (storm events, dense water cascading) controlling the shelfslope exchanges (Ulses et al., 2008).

A downscaling method, described by Ulses et al. (2005) and Guizien et al. (2006), using two levels of grid nesting was used for the simulations. The first domain (40 sigma-step vertical levels and $3 \mathrm{~km}$ horizontal resolution) extends from the Gulf of Valencia to the Ligurian Sea $\left(0.34^{\circ} \mathrm{W}-10.95^{\circ} \mathrm{E} \times 38.26^{\circ} \mathrm{N}-45.61^{\circ} \mathrm{N}\right)$. The model was initialized and forced by daily outputs of the general circulation model used in the Mediterranean Forecasting System project (Tonani et al., 2007), using the variational inverse method described by Auclair et al. (2006). The domain of the second model (25 vertical levels and $1.5 \mathrm{~km}$ horizontal resolution) covers the Gulf of Lions as indicated in Fig. 1.

For the atmospheric forcing, the 6-h outputs (radiative solar and long-wave fluxes, surface pressure, air temperature, relative humidity and wind velocity) of the high-resolution meteorological model ALADIN from Météo-France (French meteorological office) were used. The wind stress and the heat fluxes were computed with bulk formulae (Geernaert, 1990) using the air parameters provided by the model ALADIN and the sea surface temperature computed by the model SYMPHONIE.

The fresh water inputs from the main rivers of the Gulf of Lions were taken into account. Daily discharges supplied by the "Compagnie Nationale du Rhône", the 
"Banque Hydro" and the "Agència Catalana de l'Aigua" were specified at the river mouths. The temperature in all rivers was set following measurements in the Rhone River (Poirel et al., 2001), with a maximum value of $22^{\circ} \mathrm{C}$ in October (beginning of the simulation) and a minimum value of $7{ }^{\circ} \mathrm{C}$ in January and February.

\subsubsection{The wave model}

Wind generated waves were computed using the current operational NOAA (National Oceanic and Atmospheric Administration) wave model Wavewatch III (Tolman, 1997), modified by Ardhuin et al. (2007a) in order to use the wind-wave generation and dissipation parameterizations of Janssen et al. (1994). These parameterizations were found to give generally better growth at short fetch, with still important biases in the presence of swells (Ardhuin et al., 2007a). This parameterization generally provides the best results in the analysis of Mediterranean storms (Ardhuin et al., 2007b).

The model covers the whole western Mediterranean $\left(-5.6^{\circ} \mathrm{E}-16.3^{\circ} \mathrm{E} \times 31^{\circ} \mathrm{N}-45^{\circ} \mathrm{N}\right)$ with a resolution of $0.1^{\circ}$. It was forced by the wind outputs of the ALADIN $\left(0.1^{\circ}\right)$ and ARPEGE $\left(0.25^{\circ}\right.$ in the Mediterranean Sea $)$ meteorological models from Météo-France. No forcing was applied at the open boundaries. The wave model outputs used in the sediment transport simulation were 3-h significant height, mean period and direction.

\subsubsection{The sediment transport model}

The sediment transport sub-model aims at simulating the resuspension induced by a wave-current combined flow, the discharges from rivers and the dispersal of suspended sediment, by considering a multi-grain size class approach. We mainly study fine-grained sediments that are likely to transport adsorbed chemical and biogeochemical elements over large distances. However, given that (i) the sea floor of the Gulf of Lions is covered by sediments ranging from clay to sand and that (ii) a small amount of sand added to a muddy bed may modify erosion characteristics and vice versa (Panagiotopoulos et al., 1997; van Ledden et al., 2004), coarse sediment should be considered. Therefore we used five sediment size classes of primary (individual) particles from clay to coarse sand, one class of clay, 2 classes of silt and 2 classes of sand (Table 1), according to the Wentworth classification (1922).

Flocculation processes were not included in the model. Nevertheless, given that aggregation plays a major role on horizontal and vertical fluxes of particulate matter by enhancing settling velocity (Gardner and Walsh, 1990; Curran et al., 2007), aggregate classes were incorporated on the basis of in situ grain size measurements collected during a previous experiment (Durrieu de Madron et al., 2005), which indicated the persistent presence of 100-200 $\mu \mathrm{m}$ flocs built from clay and fine silt particles. Comparing these in situ measurements with size distribution of sonified samples, we estimated that $73 \%$ of clay particles and $23 \%$ of fine silt particles were aggregated during resuspension into flocs of $130 \mu \mathrm{m}$ diameter, the rest remaining as primary particles.

The settling velocity was set according to the median grain size diameter of each size class, using Stokes' law (Simons and Sentürk, 1977) for primary particles whose diameter is smaller than $100 \mu \mathrm{m}$ and using Zanke's (1977) formula for coarser primary particles. We used the estimates of Agrawal and Pottsmith (2000) to compute the settling velocity of aggregates. The sediment density for primary particles was fixed at $2650 \mathrm{~kg} \mathrm{~m}^{-3}$. The density of aggregates was set at $1102 \mathrm{~kg} \mathrm{~m}^{-3}$ using the formulation of Hill et al. (1998).

The suspended sediment concentration $C^{i}$ for each size class i was computed using the advection-diffusion equation:

$\frac{\partial C^{i}}{\partial t}+\frac{\partial u C^{i}}{\partial x}+\frac{\partial v C^{i}}{\partial y}+\frac{\partial\left(w-w_{s}\right) C^{i}}{\partial z}=-\frac{\partial F^{i}}{\partial z}$,

where $u, v$, and $w$ are the three components of the current velocity, $F^{i}$ is the vertical turbulent flux given by $-K_{z} \partial C / \partial z$, $K_{z}$ is the vertical diffusivity calculated by the hydrodynamic model, and $w_{s}{ }^{i}$ is the sediment settling velocity. A positive definite, upwind advection scheme is used (with a corresponding diffusion in the direction of the $x$-component of the current, $u$, given by $|u| \Delta x / 2)$. Particulate matter inputs from the atmosphere (Heussner et al., 2006) and at the eastern entrance of the Gulf of Lions (Lapouyade and Durrieu de Madron, 2001; pers. comm. Gatti) are negligible with respect to resuspension and river inputs during a period marked by strong storms and floods. Moreover, due to a lack of information on biological production during the study period, the pool of phytoplanktonic particles was not taken into account in the model. Therefore, the atmospheric deposition, the inputs at the open boundaries and the biological production were considered as null, and the resuspension and river inputs constituted the boundary conditions of Eq. (1).

Table 1

Sediment grain size distribution and properties used in calculations: median diameter $(\mu \mathrm{m})$, settling velocity $\left(\mathrm{m} \mathrm{s}^{-1}\right)$ and density $\left(\mathrm{kg} \mathrm{m}^{-3}\right)$

\begin{tabular}{llllll}
\hline Particle classes & $\begin{array}{l}\text { Clay } \\
0-4 \mu \mathrm{m}\end{array}$ & $\begin{array}{l}\text { Fine silt } \\
4-16 \mu \mathrm{m}\end{array}$ & $\begin{array}{l}\text { Coarse silt } \\
16-63 \mu \mathrm{m}\end{array}$ & $\begin{array}{l}\text { Fine sand } \\
63-250 \mu \mathrm{m}\end{array}$ & $\begin{array}{l}\text { Coarse sand } \\
>250 \mu \mathrm{m}\end{array}$ \\
\hline $\begin{array}{l}\text { Corresponding } D_{50}(\mu \mathrm{m}) \\
\text { Settling velocity }\left(\mathrm{m} \mathrm{s}^{-1}\right)\end{array}$ & 2.4 & 8.4 & 31.6 & 119 & 671 \\
$\rho\left(\mathrm{kg} \mathrm{m}^{-3}\right)$ & 2650 & $5.4 \times 10^{-5}$ & $7.6 \times 10^{-4}$ & $9.2 \times 10^{-3}$ & $\begin{array}{l}\text { Aggregates } \\
8.7 \times 10^{-2}\end{array}$ \\
\hline
\end{tabular}


3.1.3.1. Bottom boundary condition. The bottom boundary condition of Eq. (1) is given by the erosion flux at the bed level. Given that the Gulf of Lions sediments consist of a mixture of clay, silt and sand in highly variable proportions, we distinguished between cohesive and noncohesive behaviors for the representation of the erosion process in the different sedimentary environments. Historically, many investigations addressed the behavior of noncohesive sand beds and cohesive mud beds separately. More recently, as reported by van Ledden et al. (2004), several experiments have shown that the erosion characteristics can dramatically change when small amounts of mud are added to a sand bed and vice versa. Based on laboratory and field experiments, several researchers identified a transition from a non-cohesive to cohesive behavior at clay contents of 3-14\% (Raudkivi, 1990; Panagiotopoulos et al., 1997; van Ledden et al., 2004). This criterion was implemented in the model to switch between cohesive and non-cohesive formulations of erosion flux, using a constant value of a critical clay fraction: at each time step, the clay fraction in the superficial sediment of each cell grid, larger or smaller than the critical one, determines the formulation used. We fixed the value of the critical clay fraction at $6 \%$. In the model, the clay fraction is smaller than $6 \%$ near the coast, from 0 to $\sim 40 \mathrm{~m}$ depth, except in prodelta areas. A sensitivity study to this value is presented in Section 4.5.4. Several studies that aimed at estimating erosion rates have established formulations for these two types of bed. For non-cohesive sediments, erosion essentially varies according to sediment size characteristics while, for cohesive beds, erodability depends on the bed properties including biological and chemical factors-bioturbation, water content, organic matter content, etc. - and the age of deposit (Berlamont et al., 1993). The erosion fluxes for non-cohesive sediments were computed according to Smith and McLean (1977) and for cohesive sediments using the Partheniades' law (1962) (see Appendix A).

The bottom shear stress under combined wave and current conditions was calculated using the method of Soulsby et al. (1993) with the parameterization of Fredsøe (1984) (see Appendix B). The bottom roughness $z_{0}$ was evaluated by distinguishing silty and sandy beds (see Appendix B). The bed armoring process takes into account the reduction of available fine-grained sediments for resuspension due to the protective effect of coarser grains. Thus this process is of considerable importance in modeling storm resuspension on the shelf where bed sediment consists of sand-mud mixtures (Zhang et al., 1999; Ferré et al., 2005). It was implemented in the module following Harris and Wiberg (2001) (see Appendix C).

3.1.3.2. River inputs. Suspended sediment concentrations were specified at the Gulf of Lions river mouths. Sediment discharges were deduced from water discharges through empirical relations, using the estimation of Sempéré et al. (2000) for the Rhone River, of Pethelet-Giraud et al. (2003) for the Herault River, of Serrat (1999) for the Agly River and of Serrat et al. (2001) for the Tet River. Due to the lack of information, sediment discharges of the Aude and Orb Rivers were determined using the relation established for the nearby Herault River; likewise, the suspended sediment concentration set at the Tech River was deduced from the relationship of the nearby Tet River.

The grain size distribution of the Rhone River suspended sediment matter and its change during the December 2003 flood were measured by Antonelli et al. (2008). They showed an increase of sand fraction from $2 \%$ before the flood, to $22 \%$ around the flood peak, together with a decrease of silt fraction. The clay fraction was nearly constant, around $13 \%$. For non-flood periods, constant fractions corresponding to the values recorded before the flood were fixed in the model. During floods, we imposed variable fractions using a sinusoidal relation based on the observations. As no further information on the granulometry was available, we decided to evenly distribute the measured silt concentration between the two modeled silt size classes, while all the observed sand concentration was attributed to the fine sand class to avoid immediate sedimentation. At the small river (Herault, Orb, Aude, Agly, Tet and Tech Rivers) mouths, we applied a constant value for the suspended sediment concentration of clay, silts and fine sand, estimated according to measurements in the Tet River (Garcia-Esteves, 2005). The grain size distribution was set at $69 \%$ silt particles and $24 \%$ clay particles. Aggregates were formed from clay and fine silt following the rule described above for resuspension. This is a very crude approximation as flocculation probably depends on the water (through turbulence) and sediment discharges. Dedicated measurements would be necessary to improve this point and possibly to calibrate and validate a flocculation model.

3.1.3.3. Initial conditions. The initial suspended sediment concentration was set to zero over the whole domain. The initial grain size distribution in the sediment (Fig. 1) was specified by interpolating the sediment grain size inferred from 787 cores collected over the whole Gulf (pers. comm. S. Charmasson, V. Roussiez, A. Grémare, N. Frumholtz, S. Berné). At the initial state, the sea bed was assumed to be homogeneous on the vertical axis.

\subsection{Field observations}

\subsubsection{Near-bottom current and suspended sediment concentration records}

Time series of near-bottom current and suspended sediment concentration were recorded by moored instruments at $300 \mathrm{~m}$ depth in seven submarine canyon heads in the Gulf of Lions: the Cap de Creus, Lacaze-Duthiers, Aude, Herault, Petit-Rhone, Grand-Rhone and Planier Canyons (Fig. 1). On each of these canyon heads, one Aanderaa RCM9/11 current meter equipped with temperature, conductivity and optical backscattering sensors 
was installed $4 \mathrm{~m}$ above bottom (mab) from November 5 , 2003 to May 5, 2004. The sampling interval of the current meters was set to $20 \mathrm{~min}$. Temperature and conductivity sensors were calibrated using CTD measurements performed next to the mooring lines in November 2003, February and March 2004 (Palanques et al., 2006). PPS3 sequential sediment traps with a sampling interval of 15 days were located on each mooring at 30 mab. The measured total mass fluxes are presented and analyzed in Bonnin et al. (this issue).

A bottom tripod was also deployed at the Tet prodelta study site $(27 \mathrm{~m}$ water depth) from November 26 to December 12, 2003 and from February 4 to March 18, 2004. Water turbidity was measured using three D\&A Instruments Optical Backscatter Sensors (OBS-3) mounted on a tripod frame at 15,50 and $90 \mathrm{cmab}$ collecting data every $3 \mathrm{~h}$ in bursts of $20 \mathrm{~min}$ at $2 \mathrm{~Hz}$ (Guillén et al., 2006). Current profiles were obtained by a bottom-mounted ADCP RDI Sentinel $600 \mathrm{kHz}$ model equipped with a wave pressure sensor. Currents were continuously measured at $1 \mathrm{~Hz}$ and averaged every $3 \mathrm{~h}$. All turbidity data recorded in FTU were converted into suspended sediment concentrations following the empirical relationship derived by Guillén et al. (2000).

Uncertainties for current speed, $\Delta V$, and suspended sediment concentration, $\Delta C$, are derived from instrument precision and calibration (e.g., conversion from turbidity to SSC). The uncertainty in current speed is estimated to be $\Delta V=4.5 \times 10^{-3} \mathrm{~m} \mathrm{~s}^{-1}$ (statistical precision/standard error from Aanderra RCM9/11 brochure) and the uncertainty in suspended sediment concentration to be $\Delta C=0.2 \mathrm{mg} \mathrm{L}^{-1}=$ $2 \times 10^{-4} \mathrm{~kg} \mathrm{~m}^{-3}$ (minimum guess from standard error on SSC estimates from filters, the most important source of uncertainty; the uncertainty associated with the turbidity sensor accuracy is likely to be much smaller).

\subsubsection{Wave data}

Wave data were obtained from non-directional wave buoys located off Sète (central coastal sector: depth $=32 \mathrm{~m}$, lat $=43^{\circ} 19.7^{\prime} \mathrm{N}$, lon $=3^{\circ} 39.05^{\prime} \mathrm{E}$-data from Service Maritime et de Navigation du Languedoc Roussillon), in Camargue (northeastern coastal sector: lat $=43^{\circ} 21^{\prime} \mathrm{N}$, lon $=4^{\circ} 34^{\prime}$ E-data from CETMEF), offshore of the Gulf of Lions $\left(\right.$ depth $=2300 \mathrm{~m}$, lat $=42.1^{\circ} \mathrm{N}$, lon $=4.7^{\circ} \mathrm{E}$-data from Mété-France) and from the ADCP measurements off the Tet River mouth (southwestern coastal sector: depth $=27 \mathrm{~m}$, lat $=42^{\circ} 42 \cdot 25^{\prime} \mathrm{N}$, lon $=3^{\circ} 04^{\prime} \mathrm{E}$ ).

\section{Results and discussion}

The next sections describe forcing variables (wind, wave and rivers) and in situ observations (currents and suspended sediment concentrations) for comparison with the model outputs. Then we analyze the impact of the most intense storm and flood events on (i) the sediment dynamics of the shelf and on (ii) the export of sediment to the slope. The uncertainties associated with the choice of model parameters are then estimated. Finally, we put these results in perspective by considering the interannual variability of the off-shelf sediment export in the Gulf of Lions, and by comparing them with other regions.

\subsection{Wind, wave and river climate}

Autumn was marked by a strong southeastern onshore wind episode in early December (Fig. 2a) that generated large waves (Fig. 2b). Two brief events with enhanced wave activity occurred on December 4 and December 8 , 2003. During the first event, wind speed reached $16 \mathrm{~m} \mathrm{~s}^{-1}$ (Fig. 2a). Significant wave height increased to $6 \mathrm{~m}$ in the eastern sector (Fig. 2b) and $8 \mathrm{~m}$ in the western sector (Fig. 3). The meteorological conditions caused the flooding of all rivers of the Gulf. In particular, the daily water discharge of the Grand-Rhone River increased to $9346 \mathrm{~m}^{3} \mathrm{~s}^{-1}$ (Fig. 2c) and sediment discharge peaked at $\sim 23,000 \mathrm{~kg} \mathrm{~s}^{-1}$ (Fig. 2d). This flood event had an estimated recurrence period of $\sim 75$ years (Palanques et al., 2006). During the second storm on December 8, rather high values of significant wave height $(>4 \mathrm{~m})$ were observed along the western coast (Fig. 3).

A second flood of the Rhone River began in midJanuary with a discharge peak of $\sim 4000 \mathrm{~m}^{3} \mathrm{~s}^{-1}$ and ended in late January when the river discharge dropped below $3000 \mathrm{~m}^{3} \mathrm{~s}^{-1}$ (Fig. 2c). During wintertime, intense continental winds blew over short periods of time (Fig. 2a). Comparison with meteorological observations (collected by Météo-France) from winters 1973 to 2001 revealed that off-shore winds blowing during winter 2004 were low in frequency, duration and magnitude (Ulses et al., 2008). This suggests that cooling of shelf water was reduced during the studied winter.

The late winter and early spring were characterized by several onshore wind events (late February, mid-March, late March-early April, and mid-April) (Fig. 2a). They were accompanied by only moderate increases of the Rhone River discharge and significant floods of the small rivers (Fig. 2c). The February marine wind episode corresponded to a strong storm during which significant wave height reached $5.5 \mathrm{~m}$ in the eastern sector (Fig. $2 \mathrm{~b}$ ) and $7 \mathrm{~m}$ in the western sector (Palanques et al., 2006). During this event and the mid-March event, wind reached speeds of $14 \mathrm{~m} \mathrm{~s}^{-1}$. In order to better differentiate this winter from previous ones, we determined from meteorological observations over the 1973-2001 winter periods the number of events during which eastern to southeastern winds $\left(90^{\circ}<\right.$ wind direction $<$ $180^{\circ}$ ) blew with a speed higher than $14 \mathrm{~m} \mathrm{~s}^{-1}$. During this 29-year period, only seven such events (January 17, 1973; March 21, 1974; February 24, 1978; February 11, 1979; January 15, 1982, January 13, 1998; February 7, 2001) were found, each one appearing a distinct year. Thus, the frequency of the intense onshore winds that took place during the studied winter appears to be unusual.

In summary, the deployment period was marked by rather short bursts of cold continental winds associated 

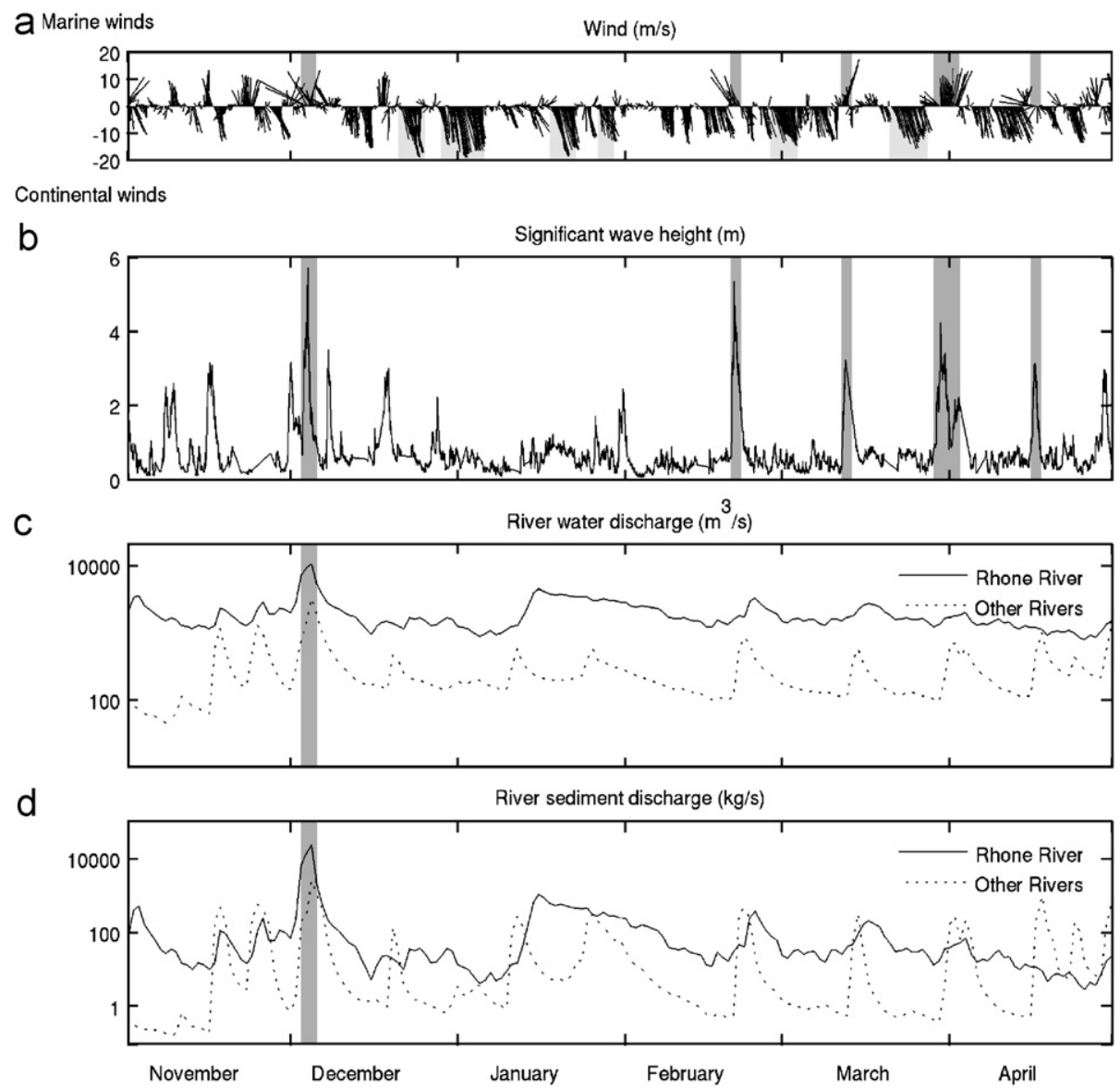

Fig. 2. Time series of (a) wind $\left(\mathrm{m} \mathrm{s}^{-1}\right)$ simulated from the ALADIN meteorological model on the Tet prodelta, (b) significant wave height ( $\mathrm{m}$ ) measured off Sète, (c) measured water discharges $\left(\mathrm{m}^{3} \mathrm{~s}^{-1}\right)$ and (d) estimated sediment discharges $\left(\mathrm{kg} \mathrm{s}^{-1}\right)$ in the rivers of the Gulf, from November 2003 to May 2004. The "other rivers" cluster includes the Herault, Orb, Aude, Agly, Tet and Tech Rivers. The gray shaded areas correspond to periods of strong wind, wave activity or river discharge. Wind sticks indicate the direction toward where the wind is blowing.

with low waves at the coast, and unusually high occurrence of strong marine winds associated with high waves. The two major storm events in December 2003 and February 2004 during which significant wave height exceeded 8 and $7 \mathrm{~m}$ in the western region respectively had an estimated recurrence interval of about 50 and 10 years (Palanques et al., 2006). The study period was also characterized by high riverine inputs. The major sediment and water discharges were supplied by the Rhone River $(80 \%$ of the total river delivery) during the intense December and moderate January floods. The December and February storms, as well as the December flood, are considered as extreme events in the following.

\subsection{Near-bottom current and suspended sediment concentration time series}

\subsubsection{Observations on the shelf}

Near-bottom currents off the Tet River reached maximum velocity during the two strong marine storms that occurred in early December and late February (Fig. 3). During these events, near-bottom currents were generally oriented toward the southeast and reached speeds larger than $40 \mathrm{~cm} \mathrm{~s}^{-1}$ (peak values from non-filtered time series, not shown). Increases in suspended sediment concentration (SSC) $90 \mathrm{cmab}$ on the shelf coincided with intensifications of currents and waves (Figs. 3 and 4). The SSC peaked at $\sim 500-700 \mathrm{mg} \mathrm{L}^{-1}$ (peak values from non-filtered time series, not shown) during the two strong marine storms (pers. comm. Guillén). With the exception of southeastern wind episodes, values of the SSC at $90 \mathrm{cmab}$ were generally lower than $100 \mathrm{mg} \mathrm{L}^{-1}$.

\subsubsection{Observations in the canyon heads}

The near-bottom current and SSC time series within the canyons, described by Palanques et al. (2006), reveal a high time and spatial variability (Figs. 3 and 4). Fluctuations were clearly larger and more frequent in the southwestern part of the Gulf, particularly in the Cap de Creus Canyon.

In autumn, the current speed and SSC were relatively low and showed high frequency fluctuations. A notable exception occurred during the severe December marine storm, when a large and brief increase of the current speed and SSC was observed in the western and central canyons 


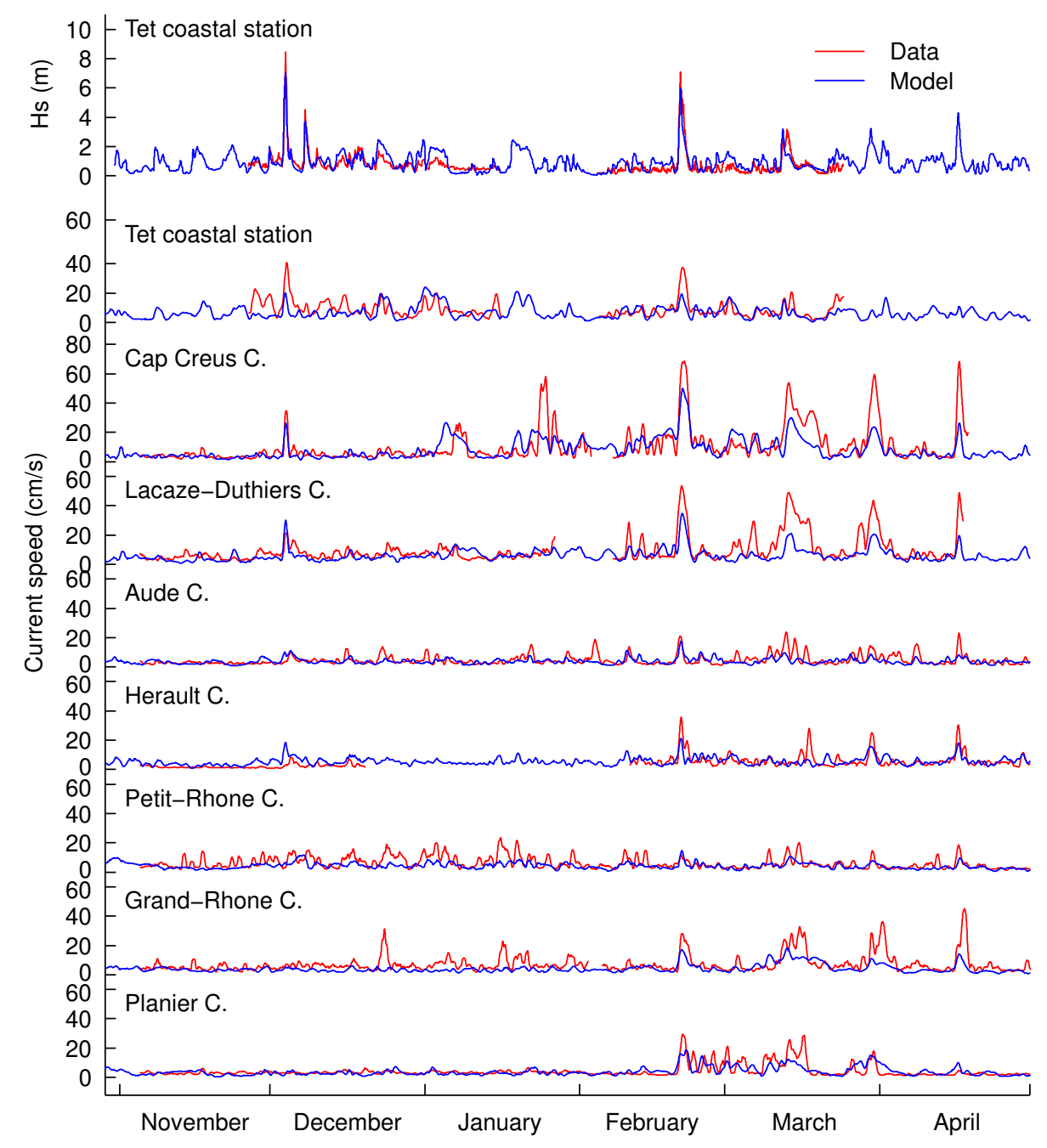

Fig. 3. Comparison of observed (red curve) and simulated (blue curve) significant wave height $(\mathrm{m})$ at the Tet coastal station (southwestern sector) and near-bottom current velocity $\left(\mathrm{cm} \mathrm{s}^{-1}\right)$ at the Tet coastal station and in the canyon heads, from November 2003 to May 2004. A Loess filter was applied to observed and simulated fields. See Palanques et al. (2006) for observed peak values in canyons.

(Cap de Creus, Lacaze-Duthiers, Aude, Herault and PetitRhone). In the Cap de Creus Canyon, the current velocity and SSC reached values of $80 \mathrm{~cm} \mathrm{~s}^{-1}$ and $48 \mathrm{mg} \mathrm{L}^{-1}$ respectively (peak values from non-filtered time series, see Palanques et al., 2006). The flow was associated with an increase of temperature and a decrease of salinity due to the advection of warmer and less saline shelf water down the canyons heads (Ulses et al., 2008).

During wintertime, when the water column was weakly stratified, strong current periods were longer and associated with temperature drops reflecting the down-slope advection of cold dense water formed on the shelf during intense continental winds (Palanques et al., 2006; Ulses et al., 2008). During the late February strong marine storm, the current speed and SSC peaked at $80 \mathrm{~cm} \mathrm{~s}^{-1}$ and $>68 \mathrm{mg} \mathrm{L}^{-1}$ in the Cap de Creus Canyon (Palanques et al., 2006). In the other canyons, SSCs were relatively low, especially in the easternmost canyons (Grand-Rhone and Planier). The following moderate storm events (mid-
March, late March-early April, mid-April) also produced an intensification of the down-canyon currents. However, the SSC increase was weak in the western canyons and absent in the eastern canyons.

Hence, large increases of the current speed and SSC on the shelf and slope were clearly correlated with extreme marine storms that occurred in early December 2003 and late February 2004. It is noteworthy that currents and SSC anomalies at the canyon heads were always associated with advection of shelf water (Palanques et al., 2006; Ulses et al., 2008).

\subsection{Evaluation of model skill}

Wave, hydrodynamic and sediment transport model outputs were compared with in situ data. A comprehensive assessment of the hydrodynamic model skill for the study period was performed by Ulses et al. (2008) with respect to hydrological and current measurements. In the present 


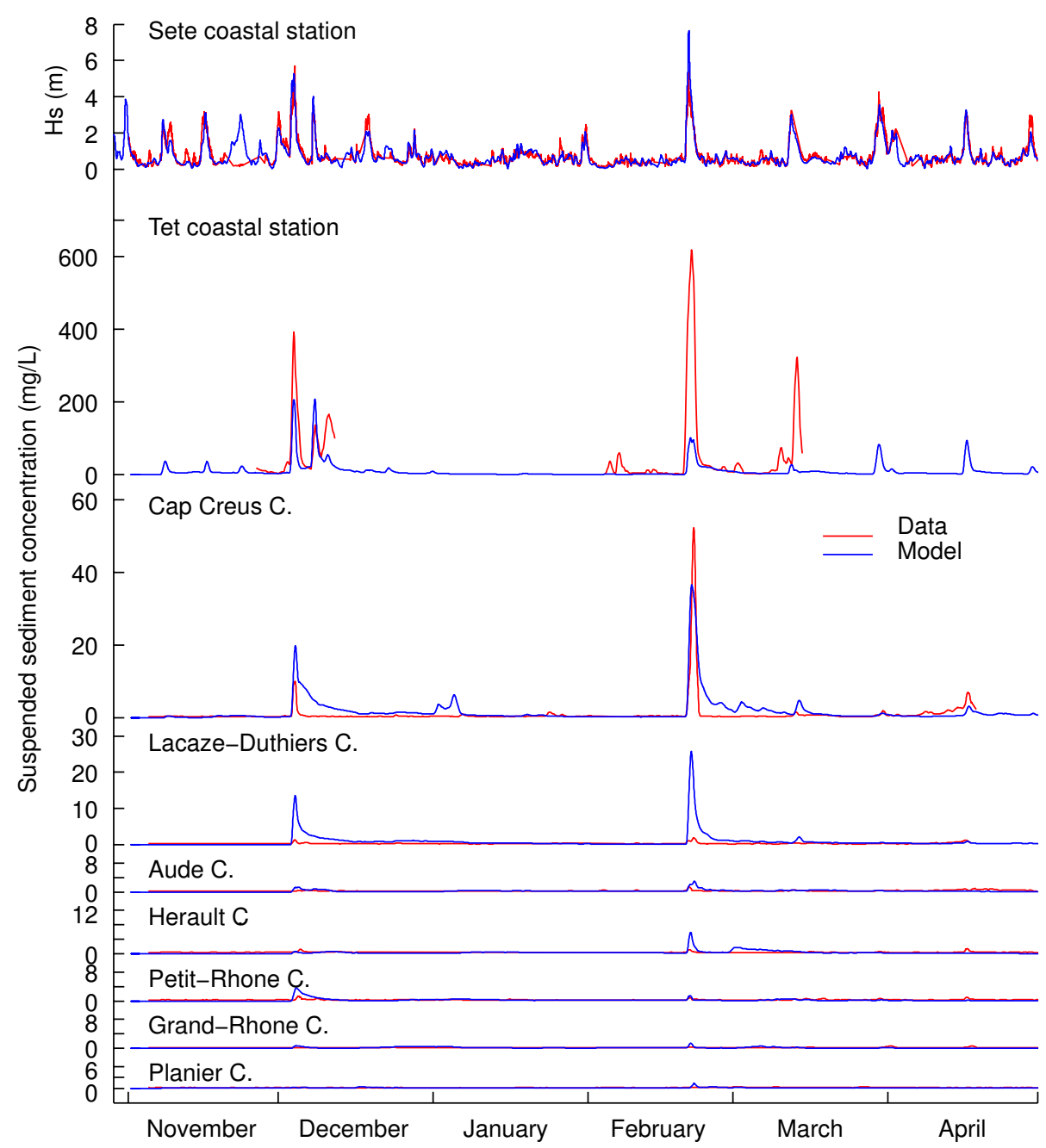

Fig. 4. Comparison of observed (red curve) and simulated (blue curve) significant wave height $(\mathrm{m})$ at the Sète coastal station (northern sector) and nearbottom suspended sediment concentration $\left(\mathrm{mg} \mathrm{L}^{-1}\right)$ at the Tet coastal station and in the canyon heads, from November 2003 to May 2004 . The peak of observed suspended sediment concentration during the February storm in the Cap de Creus Canyon was underestimated because turbidity levels exceeded the sensor range. A Loess filter was applied to observed and simulated fields. See Palanques et al. (2006) for observed peak values in canyons.

paper, we focus on the simulated and observed significant wave height, near-bottom current and suspended sediment concentration comparisons. Three different statistical quantities were computed to compare the model results and the observations: the Root Mean Square (hereafter RMS) error (Eq. (2)) and the bias (Eq. (3)), that give the amplitude of the differences between the model and the observations, and the correlation coefficient (Eq. (4)) that informs about the coherency between modeled and observed structures:

RMS error $=\left[\frac{1}{N} \sum_{n=1}^{N}\left(f_{\text {model }}^{n}-f_{\text {observation }}^{n}\right)^{2}\right]^{1 / 2}$,

where $f_{\text {model }}$ and $f_{\text {observation }}$ are the modeled and observed fields respectively and $N$ the number of time measurements.

Bias $=\frac{1}{N} \sum_{n=1}^{N}\left(f_{\text {model }}^{n}-f_{\text {observation }}^{n}\right)$

$$
\begin{aligned}
& \text { Correlation }=\frac{1}{N-1} \frac{1}{\sigma_{\text {observation }} \sigma_{\text {model }}} \\
& \quad \times \sum_{n=1}^{N}\left(f_{\text {model }}^{n}-\overline{f_{\text {model }}}\right)\left(f_{\text {observation }}^{n}-\overline{f_{\text {observation }}}\right),
\end{aligned}
$$

where $\bar{f}$ is the mean value over the $N$ time measurements and $\sigma_{\text {observation }}$ and $\sigma_{\text {model }}$ are the respective standard deviation of the recorded and simulated fields:

$$
\begin{aligned}
& \sigma_{\text {observation, model }}= \\
& {\left[\frac{1}{N} \sum_{n=1}^{N}\left(f_{\text {observation, model }}^{n}-\overline{f_{\text {observation, model }}}\right)^{2}\right]^{1 / 2}}
\end{aligned}
$$

\subsubsection{Waves}

Wave height and period were compared to observations located at four different points in the Gulf of Lions. Figs. 3 and 4 present the comparison between simulated and observed wave heights off the Tet River and off Sète, 
Table 2

RMS error of the difference, correlation coefficient and bias between observed and modeled fields, mean observed and modeled fields computed for the significant wave height (m) at the Tet, Sete, Camargue and Gulf of Lions stations

\begin{tabular}{lclrll}
\hline Stations & \multirow{2}{*}{ RMS } & Correlation & \multirow{2}{*}{ Bias } & \multicolumn{2}{l}{ Mean } \\
\cline { 5 - 6 } & & & & $H_{s_{\text {observations }}}$ & $H_{s_{\text {model }}}$ \\
\hline Tet & 0.49 & 0.82 & -0.11 & 0.92 & 1.03 \\
Sete & 0.35 & 0.89 & 0.02 & 0.79 & 0.77 \\
Camargue & 0.39 & 0.85 & -0.09 & 0.85 & 0.94 \\
Gulf of Lion & 0.54 & 0.92 & 0.2 & 1.94 & 1.74 \\
\hline
\end{tabular}

respectively. The time series show that the model is able to reproduce the time and spatial variability observed at the buoys. The different southeastern storm events with higher values along the western coast are reproduced by the model. Table 2 presents the RMS, correlation coefficient, bias and mean value of the observed and modeled significant wave heights. The largest RMS error is found offshore of the Gulf of Lions where values of wave heights were usually maximum. We note an excellent correlation (0.92) for this point. Close to the coast, the correlation is also good (between 0.82 and 0.89 ). The significant wave height is globally overestimated by the model at the Tet and Camargue stations but we note an underestimation during storm events at the Tet station by a factor of about 1.2 (Fig. 3).

\subsubsection{Near-bottom current and suspended sediment concentration}

On the shelf, bursts of current are reasonably well reproduced during marine storm events although modeled current speeds underestimate the peak intensities by a factor of $\sim 2$ (Fig. 3). Lentz et al. (in revision) showed using observations that wave forcing could be important well seaward of the surf zone, over the inner shelf, for similar values of $H_{s} / h$, where $H_{s}$ is significant wave height and $h$ is water depth. This discrepancy could then relate to the fact that interactions between wave-induced currents and the coastal circulation were not taken into account (Denamiel, 2006). It could also be caused by an underestimation of the wind intensity during the storm. The instrument measuring the wind speed at the Tet station broke down during the December storm. Therefore, this hypothesis cannot be confirmed or refuted through comparison of the meteorological model outputs with data at this location. In addition, the underestimation of the near-bottom current could also be linked to an overestimation of the bottom friction. Currents were computed independently from the sediment transport model. Thus, variations of the bed roughness were not taken into account in the current computation. The bed roughness was fixed to a constant value of $1 \mathrm{~cm}$ for the hydrodynamic simulation. In a sensitivity test, where it was fixed at $0.05 \mathrm{~cm}$, the near-
Table 3

RMS error of the difference, correlation coefficient and bias between observed and modeled fields, mean observed and modeled fields computed for current speed $\left(\mathrm{cm} \mathrm{s}^{-1}\right)$ and suspended sediment concentration $\left(\mathrm{mg} \mathrm{L}^{-1}\right)$ at the Tet station (Shelf) and at the canyon heads

\begin{tabular}{|c|c|c|c|c|c|}
\hline \multirow[t]{2}{*}{ Stations } & \multirow[t]{2}{*}{ RMS } & \multirow[t]{2}{*}{ Correlation } & \multirow[t]{2}{*}{ Bias } & \multicolumn{2}{|l|}{ Mean } \\
\hline & & & & $f_{\text {observations }}$ & $f_{\text {model }}$ \\
\hline \multicolumn{6}{|l|}{ Current speed } \\
\hline Shelf & 5.64 & 0.50 & 1.70 & 8.75 & 7.05 \\
\hline Cap Creus C. & 8.58 & 0.73 & 2.09 & 10.86 & 8.77 \\
\hline Lacaze-Duthiers C. & 7.45 & 0.72 & 3.47 & 9.71 & 6.24 \\
\hline Aude C. & 3.29 & 0.44 & 0.78 & 4.72 & 3.94 \\
\hline Herault C. & 3.99 & 0.52 & -0.99 & 4.80 & 5.80 \\
\hline Petit-Rhone C. & 4.09 & 0.48 & 2.05 & 6.20 & 4.14 \\
\hline Grand-Rhone C. & 5.95 & 0.58 & 3.26 & 7.40 & 4.13 \\
\hline Planier C. & 3.33 & 0.62 & 0.36 & 4.26 & 3.89 \\
\hline \multicolumn{6}{|c|}{ Suspended sediment concentration } \\
\hline Shelf & 93.7 & 0.65 & 37.09 & 54.28 & 17.23 \\
\hline Cap Creus C. & 2.42 & 0.80 & -0.76 & 1. & 1.75 \\
\hline Lacaze-Duthiers C. & 2.17 & 0.65 & -0.60 & 0.38 & 0.98 \\
\hline Aude C. & 0.30 & 0.23 & 0.05 & 0.34 & 0.30 \\
\hline Herault C. & 0.53 & 0.20 & 0.09 & 0.43 & 0.34 \\
\hline Petit-Rhone C. & 0.33 & 0.50 & 0.08 & 0.34 & 0.25 \\
\hline Grand-Rhone C. & 0.17 & 0.11 & 0.05 & 0.18 & 0.13 \\
\hline Planier C. & 0.15 & 0.24 & 0.11 & 0.17 & 0.06 \\
\hline
\end{tabular}

bottom current speed was increased by more than $10 \mathrm{~cm} \mathrm{~s}^{-1}$ during the December storm.

The model also reproduces the temporal variation of the near-bottom SSC off the Tet River mouth marked by significant increases during storm events (Fig. 4). Nevertheless, the modeled SSC peak produced by the late February storm is clearly weaker (by a factor of 6) than the one observed. Bourrin et al. (2007) observed, after the December 2003 flood, a 2-cm fluffy layer, corresponding to a mixture of mud and organic material at the top of cores that was still present before the February 2004 storm. A pelitic fraction of $\sim 60 \%$ was measured in this superficial sediment. In the model, it is notably smaller $(\sim 10 \%)$. Thus, the underestimation of the modeled fraction of fine particles in the sediment could explain this discrepancy. In general, the agreement between model and observations is better in autumn than in winter. The RMS error for the current velocity and the SSC is found to be $5.64 \mathrm{~cm} \mathrm{~s}^{-1}$ and $93.7 \mathrm{~m} \mathrm{~L} \mathrm{~L}^{-1}$, respectively (Table 3 ). The correlation coefficient is 0.5 for the current velocity and 0.65 for the SSC.

The modeled spatial and time variations of the nearbottom current speed and SSC at the canyon heads are consistent with observations. The model represents the increase of current speed observed during storm events in the western canyons (Cap de Creus, Lacaze-Duthiers, Aude, Herault) (Fig. 3). In the eastern Planier Canyon, the modeled intensifications of current between late February and early April agree reasonably well with the measurements. More generally in the various canyons, the biases between simulated and observed current intensity show that the model globally underestimated the observations 
(Table 3). This underestimation is partly caused by the poor resolution of the model $(1.5 \mathrm{~km})$ relative to the canyon width $(2-3 \mathrm{~km})$, which did not allow representation of the complexity of circulation in the canyon. By increasing the horizontal resolution from 1500 to $500 \mathrm{~m}$ with a nested model restricted to the western region of the Gulf of Lions (Ulses et al., 2008), the simulated current peaks during marine storms were increased by about $5 \mathrm{~cm} \mathrm{~s}^{-1}$ and the bias was reduced from 2.1 to $0.3 \mathrm{~cm} \mathrm{~s}^{-1}$ in the Cap de Creus Canyon.

The order of magnitude of the modeled SSC in the various canyons agrees generally well with observations (Fig. 4, Table 3). However, the model globally overestimates the data in the western canyons (Cap de Creus and Lacaze-Duthiers) (see biases in Table 3). These canyons show strong acrossand along-slope variabilities that make difficult the comparison with data. We note a slower decrease of SSC after the storms for these canyons in the model. This discrepancy could be partly explained by the vertical resolution near the bottom that does not allow the model to represent precisely the sedimentation in the bottom boundary layer of the canyon. Moreover, large aggregates of $50-1000 \mu \mathrm{m}$ were observed in the Cap de Creus Canyon (pers. comm. Thomsen). In the model, aggregate processes were roughly represented and only one size class of aggregates was taken into account. Therefore, this discrepancy could be also attributed to a too small settling velocity of the modeled particles. In the Cap de Creus Canyon, modeled SSC is overestimated during the December storm and underestimated during the February storm. SSC in February reached the upper limit of the OBS sensor in this canyon. Thus, we have to keep in mind that the observed SSC reached even higher values than $68 \mathrm{mg} \mathrm{L}^{-1}$. The modeled peaks of SSC are overestimated in the Lacaze-Duthiers Canyon. SSC peaks are correctly simulated during storm events in the eastern and central canyons.

The RMS error for current velocity and SSC are maximum in the Cap de Creus Canyon where the mean signals were the largest. For both signals, we note a rather good correlation ( 0.73 for current speed, 0.80 for SSC). In the central and eastern canyons (Aude, Herault, PetitRhone, Grand-Rhone, Planier) the simulated and observed fields show a bad correlation (smaller than 0.5) for SSC. The small values and variations recorded in these canyons probably make the diagnostic for SSC insignificant considering the uncertainties on measurements and the relative simplicity of the model parameterizations.

To conclude our comparison between model outputs and data, the analysis of the correlation coefficients shows that the major events are correctly simulated in the western area (Cap de Creus and Lacaze-Duthiers Canyons) where their signature in current speed and SSC is the most intense (Palanques et al., 2006). This gives us confidence in the capacity of the model to capture the main features of the sediment transport and in estimating the export fluxes, despite the discrepancies noted in the other canyons where the SSC are clearly lower.

\subsection{Extreme meteorological events}

The observations indicate a major impact of the December 2003 and late February 2004 marine storms on current velocity and SSC both on the shelf and slope. The first marine storm event took place in autumn when the water column was still stratified. The density contrast between shelf and slope waters might then restrict the sediment transfer towards the open sea. In contrast, during the winter event, dense shelf water cascading might strengthen the sediment export.

The limited spatial coverage of measurements is not adapted to document sediment transport pathways on the shelf, the export to the slope, and the potential differences between marine storms and dense water cascading processes in terms of sediment resuspension and transport. In the following, an analysis of these processes based on the modeling results is presented.

\subsubsection{Autumnal storm and flood}

The December 3-4, 2003 storm was characterized by (i) an intense and brief (duration shorter than $9 \mathrm{~h}$ ) southeastern wind burst, (ii) a large increase of the wave height, especially along the western coast (Fig. 5a), and (iii) strong rainfall that caused flooding of all rivers. The river plumes, pressed against the coast by the wind, formed a turbid band flowing toward the southwest. An intense cyclonic circulation was generated on the shelf during this event (Fig. 5b). Strong near-bottom currents $\left(>25 \mathrm{~cm} \mathrm{~s}^{-1}\right)$ appeared on the outer shelf and on the whole southwestern shelf, where the flow was accelerated due to the narrowing of the platform.

Wave- and current-induced bottom stresses resuspended sediments on the inner shelf down to $60-\mathrm{m}$ water depth (maximal bottom shear stress $>1 \mathrm{~N} \mathrm{~m}^{-2}$ ) and, a few hours later, energetic currents also caused erosion on the outer shelf (Fig. 6a). Two areas were less affected by resuspension: the eastern part of the Gulf and a zone located in the center of the shelf between 50 and $100 \mathrm{~m}$ depth. These zones were characterized by relatively low wave and nearbottom currents (Fig. 5). Though the suspended sediment flux was predominately along-shelf, there was a convergence of cross-shelf suspended sediment flux at these depths. Sediment eroded upstream on the inner shelf by energetic wave and current shear stresses was transported towards deeper depth where turbulence was unable to maintain the delivery load in suspension. The near-bottom SSC was maximum near the coast where it varied between $2 \mathrm{~g} \mathrm{~L}^{-1}$ and $50 \mathrm{mg} \mathrm{L}^{-1}$ near the bottom. On the outer shelf, the increase of SSC simulated in a $\sim 20$-m thick bottom layer was smaller $\left(10-50 \mathrm{mg} \mathrm{L}^{-1}\right.$ near the bottom). The large thickness of this nepheloid layer is due to the high turbulence linked to strong near-bottom currents.

The shelf cyclonic circulation produced a massive convergence of water and suspended sediments at the southwestern end of the Gulf, and the region of the Cap de Creus appeared as the preferential outlet for the shelf 
a

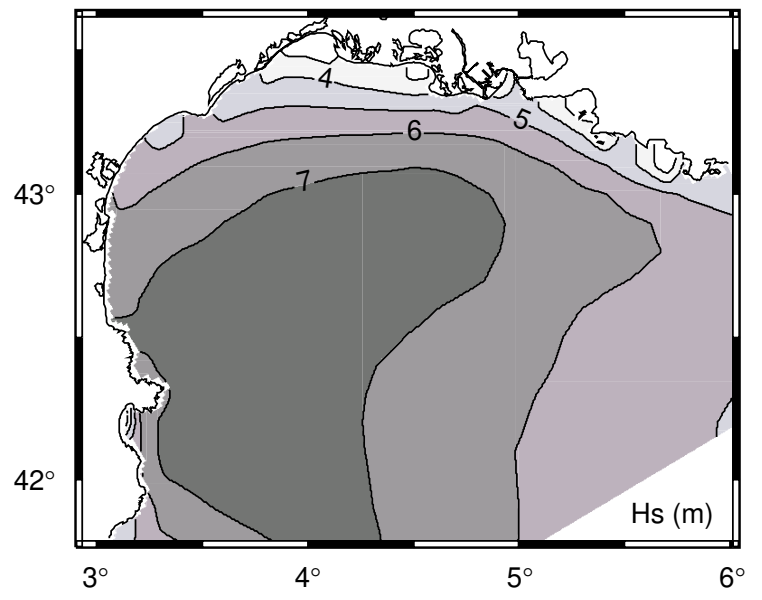

b

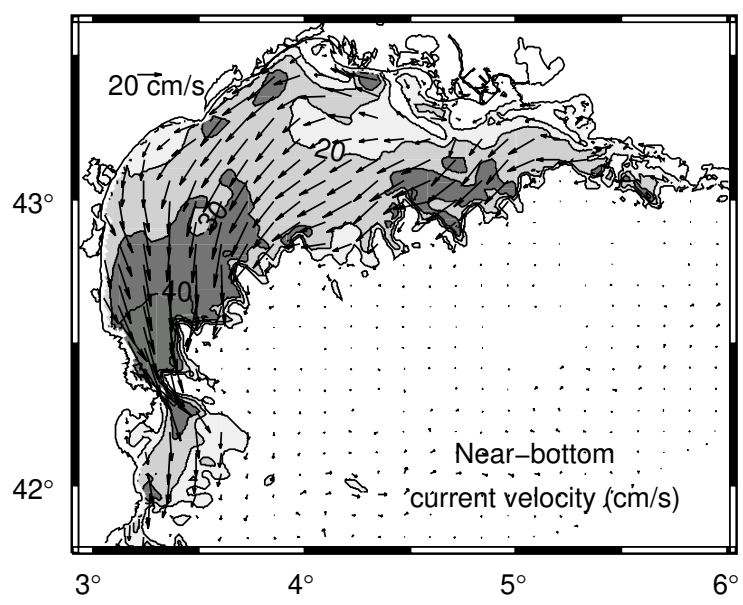

Fig. 5. (a) Significant wave height (m) and (b) near-bottom current $\left(\mathrm{cm} \mathrm{s}^{-1}\right)$ fields simulated for the December 4, 2003 at 0:00.

sediment export (Figs. $5 b$ and $6 a$ ). The excess of water that could not escape the Gulf of Lions shelf alongshore was downwelled into the nearby canyons. However, the stratification of the water column with lighter (warmer and less saline) shelf water restricted the intrusion of shelf water to $\sim 300-400 \mathrm{~m}$ deep on the slope. The suspended particulate matter was first entrained along the bottom down-canyon during the downwelling (Fig. 7a). As downwelling relaxed, the suspended sediment plume detached from the canyon floor and moved along isopycnals forming an intermediate nepheloid layer filling the canyon head (Fig. 7b). This turbid layer was finally diluted and dispersed along the shelf edge by the general circulation.

In the immediate aftermath of the storm, shelf turbid water was still transported along the shelf towards the southwestern region. Afterwards, northern winds again became dominant. The turbid Rhone plume was then pushed away from the coast and propagated southwestwards. It reached the shelf edge where it was entrained along slope by the Northern Current. Four weeks after the storm, although turbid plumes were still present along the
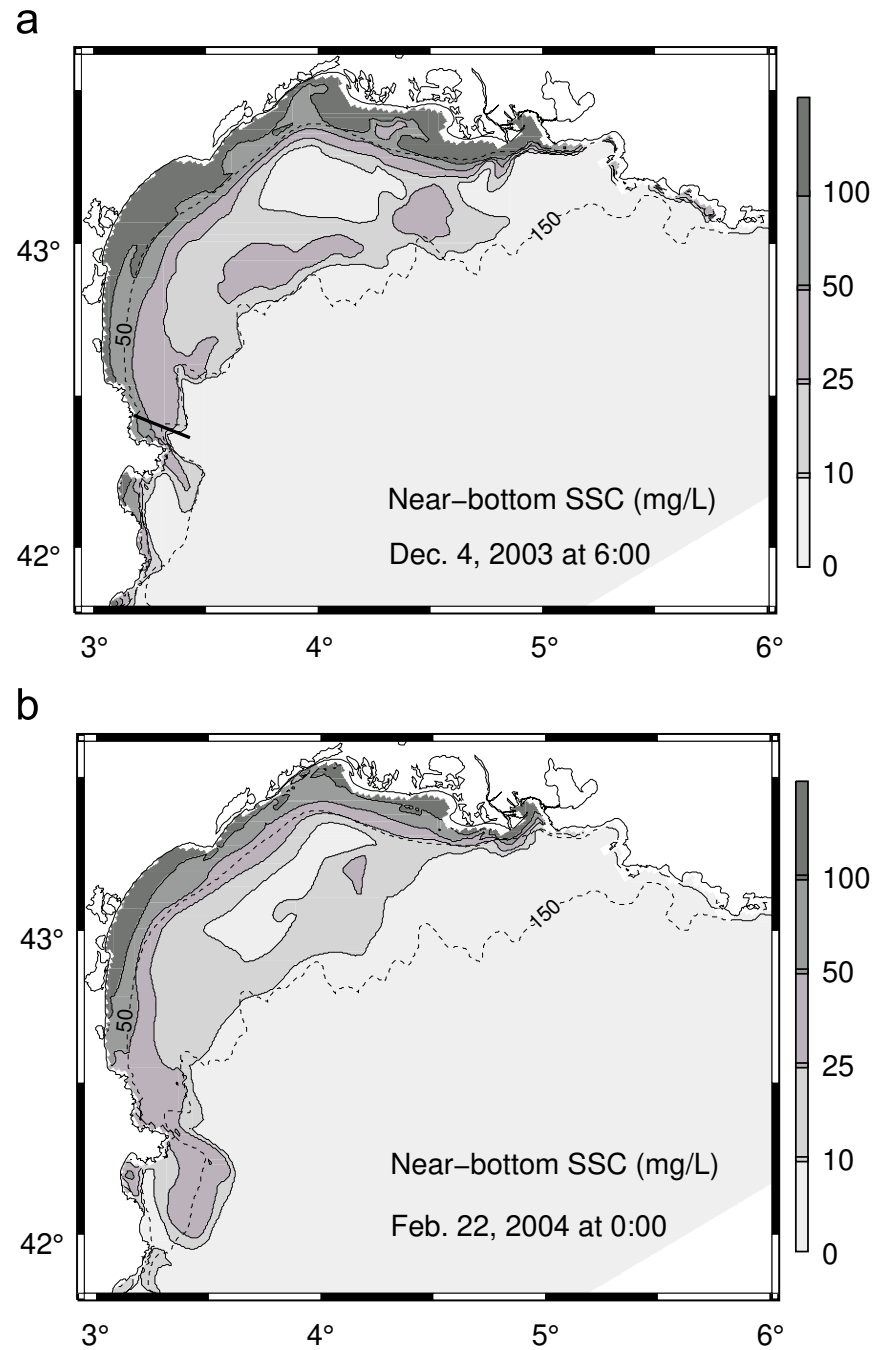

Fig. 6. Near-bottom suspended sediment concentration $\left(\mathrm{mg} \mathrm{L}^{-1}\right)$ field simulated for (a) December 4, 2003 at 6:00 and (b) February 22, 2004 at 0:00. Isobaths at 50 and $150 \mathrm{~m}$ are superimposed as dashed lines. The black line indicates the section represented in Fig. 7.

coast and on the western outer shelf, the SSC had notably decreased.

Fig. 8a depicts bed changes caused by the combination of these autumn storm and flood events. It indicates a deposit of river-borne sediment in front of the Rhone River mouth down to $100 \mathrm{~m}$ depth toward the southwest and the east. The deposit reached $20 \mathrm{~cm}$ in front of the river mouth and progressively decreased. This is in agreement with the estimate of the accumulation rate during this flood by Maillet et al. (2006) using bathymetric data. This massive deposit can be partly explained by the weaker current and wave intensity on the eastern shelf during the storm (Fig. 5). With the exception of deposits in front of river mouths, the seabed down to $20 \mathrm{~m}$ water depth was strongly eroded. Erosion also took place on the outer shelf, in particular in the southwestern end of the Gulf. Accumulation areas were located on the mid-shelf region, between 20 and $85 \mathrm{~m}$ depth, resulting from a progressive deposition during the storm relaxation period. Deposits were also 
a

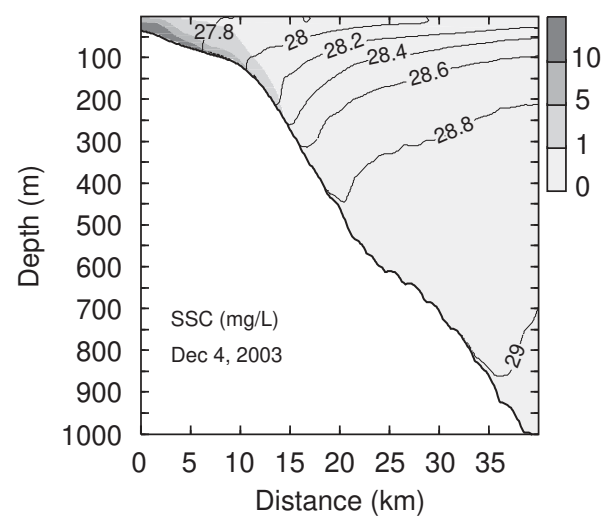

b

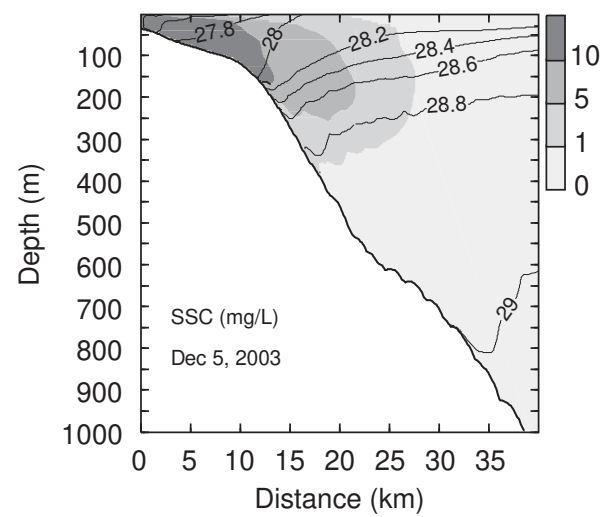

C

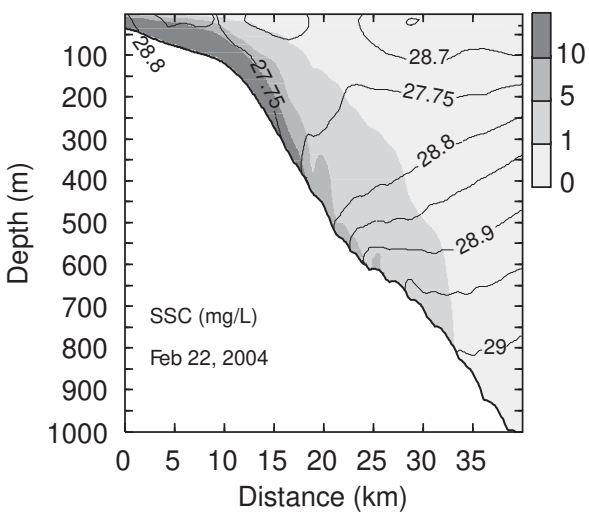

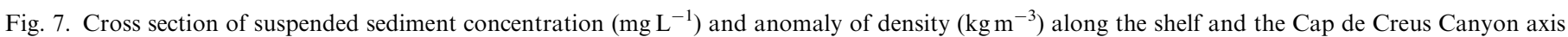

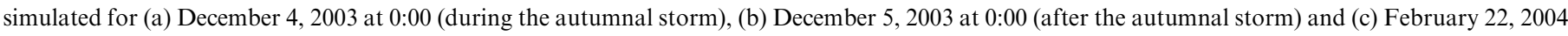
at 0:00 (during the winter storm). See Fig. 6a for section location.

detectable in the canyon heads. This is consistent with the downward particle fluxes collected by sediment trap in the Lacaze-Duthiers Canyon head that showed strong fluxes associated with the December storm (Bonnin et al., this issue). Deposits in the mid-shelf region, on the outer shelf and in canyons were essentially made up of fine particles (clay and silt).

The autumnal marine storm and the associated flood thus had a significant impact on sediment transport in the whole Gulf. They caused important modifications of the sediment level and a transfer of shelf sediments towards the open sea. However, during these stratified conditions, buoyancy effects restricted the export to the upper slope.

\subsubsection{Winter storm}

The second strong storm occurred in late February 2004, after several brief events of strong and cold continental wind (Fig. 2a) that produced a cooling of shelf water and consequently the formation of dense water along the coast and on the mid-shelf region (Ulses et al., 2008). Dense shelf waters propagated then towards the southwestern slope, mostly under the effect of gravity and continental windinduced circulations. A part of them finally cascaded in the western canyons (Cap de Creus, Lacaze-Duthiers, Aude and Herault Canyons).
During the February storm, significant wave height exceeded $4 \mathrm{~m}$ in the Gulf, except in the protected northern bays (not shown). The cyclonic circulation generated by the southeastern wind strongly accelerated the flushing of dense waters present on the middle of the shelf to the western slope (Ulses et al., 2008). Moreover, dense water cascading amplified the marine storm-induced downwelling in the canyons.

As in the December event, resuspension during the February event took place on the inner and outer shelves (Fig. 6b) and resuspended shelf sediments were transported to the southwestern end of the Gulf. During this winter storm, sediments were additionally resuspended on the western flank of the Cap de Creus and Lacaze-Duthiers Canyons where high shear stresses $\left(>1 \mathrm{~N} \mathrm{~m}^{-2}\right)$ were produced by the combination of dense water cascading and downwelling. Sediment in suspension within the dense water plume was transferred towards deeper reaches of these two canyons, down to the plume equilibrium level (about $700 \mathrm{~m}$ depth) (Fig. 7c). Afterwards, the near-bottom turbid layer that extended between 150 and $700 \mathrm{~m}$ depth spread southwards along isobaths (Fig. 6b).

Fig. 8b displays the modeled impact on the seabed elevation over the extreme winter storm and moderate river floods that took place after the storm. Inputs of sediment 
a

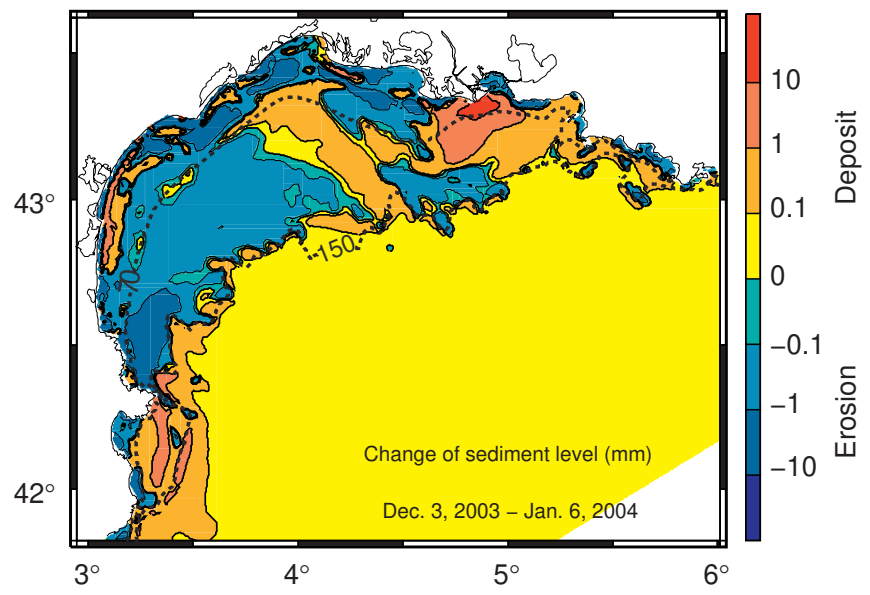

b

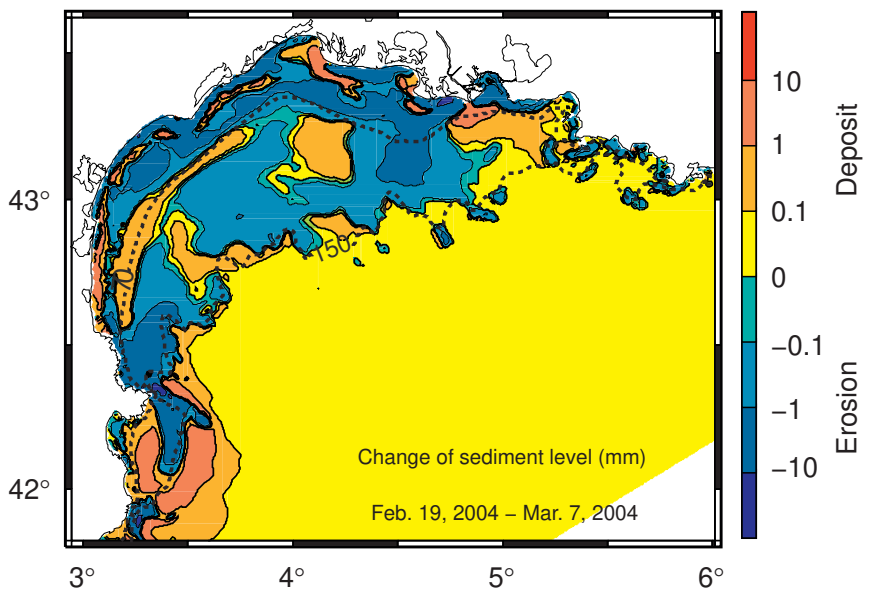

Fig. 8. Impact of the early December 2003 (a) and late February 2004 (b) storms on the bottom sediment on the shelf and upper slope. Maps present the variation of the seabed elevation $(\mathrm{mm})$ simulated between December 3, 2003 and January 6, 2004 (a) and between February 19, 2004 and March 7, 2004 (b). Positive values represent a net deposit, whilst negative values represent net erosion. 70 and $150 \mathrm{~m}$ isobaths are superimposed as dashed lines.

from the Rhone River deposited in front off the river mouth, mostly in areas deeper than $50 \mathrm{~m}$. Net deposits were also located in the northern bays protected from energetic waves, between 20 and $30 \mathrm{~m}$ and between 50 and $80 \mathrm{~m}$ in the western and central parts of the shelf. As in the December storm, net erosion was located along a narrow band next to the shore, along a mid-shelf band between 40 and $70 \mathrm{~m}$ and on most of the outer shelf. Contrary to the December storm, sediment was not accumulated at the head and on the western flank of the western canyons (Cap de Creus and Lacaze-Duthiers), which were eroded under the effect of combined dense water cascading and storminduced downwelling. These results are in agreement with the downward particle fluxes collected by sediment trap in the Lacaze-Duthiers Canyon head. In contrast to the observed horizontal particulate fluxes, the mass flux for the February storm was much lower than that for the December storm (Palanques et al., 2006; Bonnin et al., this issue), indicating that little deposition took place in the canyon heads and that the particulate load was carried toward deeper reaches of the canyon.

In summary, the winter storm presented some differences in sediment transport features compared to the autumnal storm due to the hydrological conditions (water column stratification, river discharge intensity). The dense water cascading process produced an intensification of the storminduced downwelling and led to a transfer of shelf sediments towards a deeper region. These results and associated modeling studies conducted in the Gulf of Lions (Ferré et al., this issue; Dufois et al., this issue) suggest that specific sedimentation patterns (prodelta accumulation, mid-shelf depocenter, relative paucity of modern sediment on the outer shelf and in southwestern canyon heads) are related to the actual sediment dynamics linked mostly to episodes of floods, inshore wind-induced storms or/and off-shore wind-induced dense water cascading. Such processes have a widespread influence on northern Mediterranean margins, like the Adriatic shelf (Sherwood et al., 2004; Vilibić and Supić, 2005) or the Thermaikos shelf in the North Aegean (Estournel et al., 2005).

\subsection{Sediment budgets}

\subsubsection{Particulate matter budget}

Annual net off-shelf sediment fluxes are usually calculated as a residual value in a sediment budget based on sediment core dating and river inputs (e.g., Durrieu de Madron et al., 2000 for the Gulf of Lions; Frignani et al., 2005 in the Adriatic; Sommerfield and Nittrouer, 1999 for the Eel shelf). They generally represent a "mean" export averaged over a secular time scale (typically 100-year for ${ }^{210} \mathrm{~Pb}$ based accumulation rates). However, the present study documents the influence that a few geologically significant events (floods, eastern to southeastern storms, dense water cascading) can have on the transport and offshelf export of sediment. A budget of particulate matter for the Gulf of Lions was computed from the model outputs in order to infer the respective contribution of river inputs and of resuspension to the suspended matter stock in the shelf water and to the export off the shelf (Fig. 9a).

We estimated that $5.9 \mathrm{Mt}$ of particulate matter were supplied by rivers during the 6-month study period. The major input $(\sim 4 \mathrm{Mt})$ corresponded to the December flood, of which $92 \%$ originated from the Rhone River. The moderate Rhone flood occurring in mid-January delivered $0.7 \mathrm{Mt}$ to the shelf. We performed this estimation using a log-log relationship between water discharge and suspended particulate matter concentration (Sempéré et al., 2000). This kind of relationship generally underestimates the suspended particulate matter fluxes (Ollivier, 2006). Ollivier (2006) showed, using SSC measurements, that a large scatter in suspended particulate matter concentration can be observed at high flow during floods. The sediment discharge in the Rhone River during the December flood was also estimated, using measurements of SSC $50 \mathrm{~km}$ 


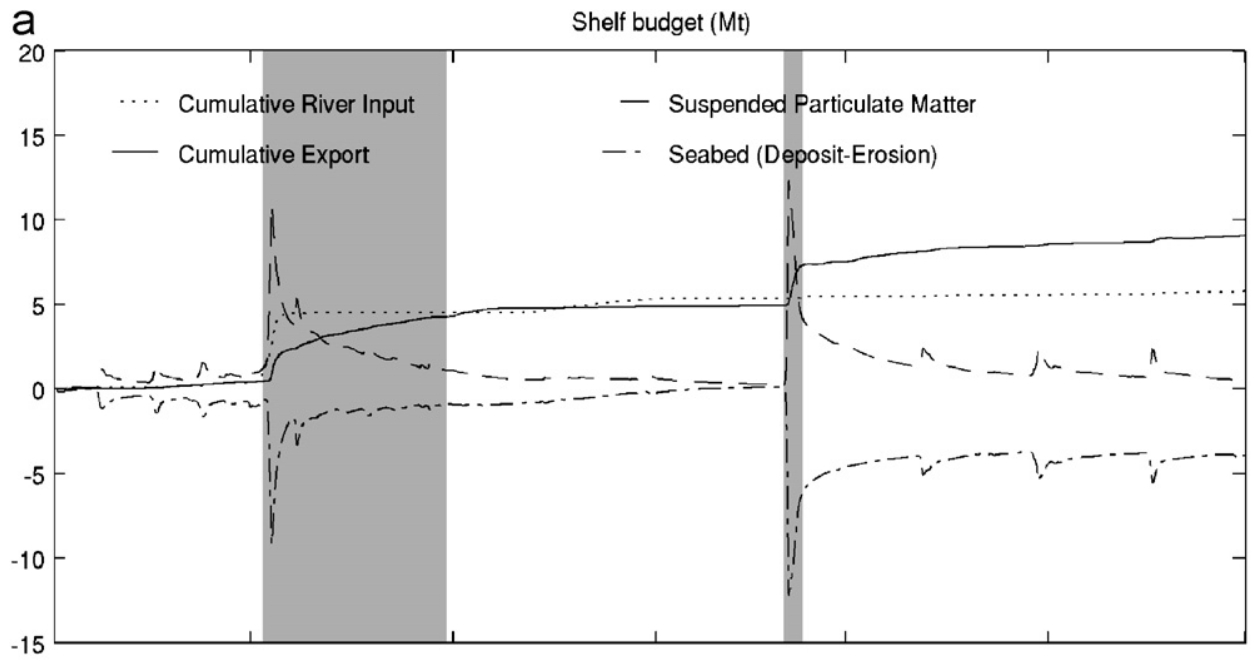

b Cumulative Export (Mt)

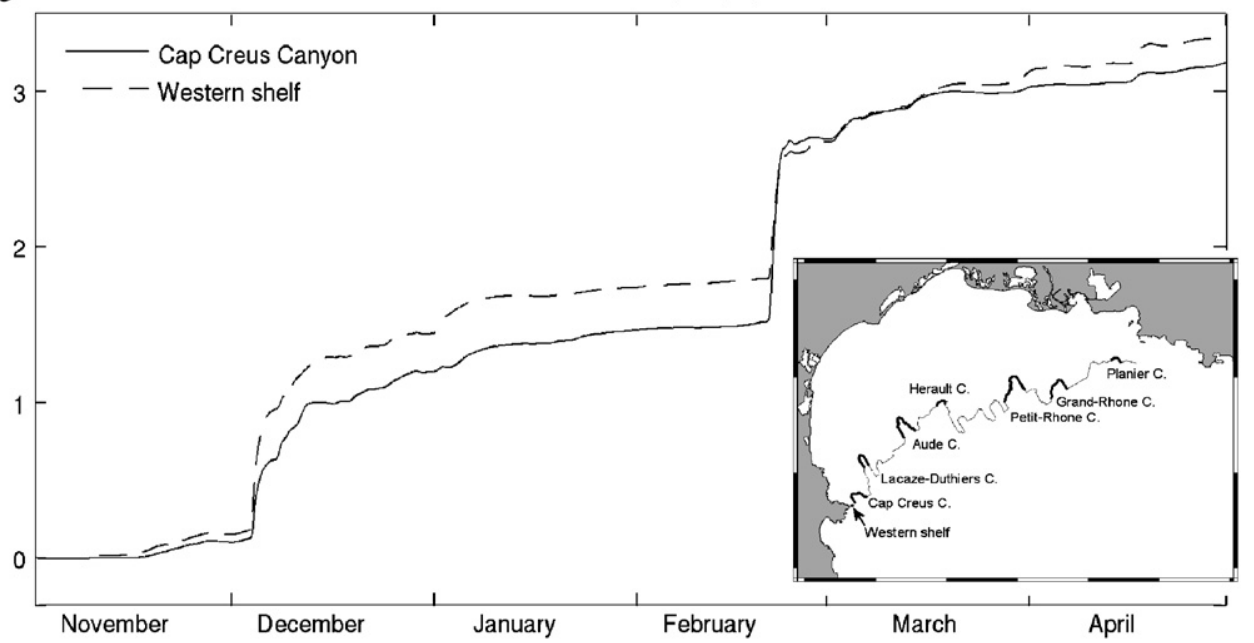

Fig. 9. (a) Modeled budget of particulate matter (Mt) on the shelf: time evolution of cumulative particulate matter discharged by rivers (dotted lines), stock of suspended matter on the shelf (dashed lines), net budget (deposit-erosion) in the sediment bed (dashed dotted lines) and cumulative export off the Gulf of Lions shelf (thick lines). Shaded areas indicate the periods where high export linked to the extreme events was modeled. (b) Modeled cumulative mass (Mt) of particulate matter exported through the Cap de Creus Canyon (thick lines) and the Cap de Creus shelf (dashed lines). The inset map shows the sections considered for the export computations.

upstream from the Rhone mouth, to be between $3.8 \mathrm{Mt}$ (Ollivier, 2006) and 5.4 $\pm 0.3 \mathrm{Mt}$ (Antonelli et al., 2008). Our estimation of the Rhone sediment discharge during the December flood $(\sim 3.7 \mathrm{Mt})$ is then probably underestimated. The total river input during the 6-month period could reach 7.9 Mt by taking into account this underestimation.

Most of the variation of the amount of sediment suspended in the shelf water took place during and after the marine storm episodes. The December 2003 increase, which reached $\sim 11 \mathrm{Mt}$, was mostly caused by the storminduced sediment resuspension $(\sim 8 \mathrm{Mt})$. Likewise the February 2004 increase, which reached $\sim 12 \mathrm{Mt}$, was almost entirely associated with the storm-induced resuspension. Thus the contribution of river supply to the suspended sediment stock in the shelf water was small. Furthermore resuspension induced by dense water flow on the shelf was insignificant with respect to resuspension induced by waves and currents. According to the comparison with the near- bottom SSC observed at the Tet station, the amount of suspended sediment could be underestimated by the model, especially during the February 2004 storm.

After the major storms, the suspended sediment stock decreased exponentially; half the stock disappeared in $\sim 1$ day, but concentrations did not return to pre-storm conditions (few $\mathrm{mg} \mathrm{L}^{-1}$ ) before 4 weeks. This dynamic resulted both from the deposition rate, linked to the particle settling and the turbulence, and to the off-shelf export rate. During the first days, particles with the highest settling velocities (sand, coarser silt and aggregates) were deposited. Deposition was favored on the outer shelf, where the density stratification confined resuspended particles near the bottom, but was slowed down in shallow waters of the inner shelf where wind and heat loss enhanced vertical mixing. The long residence time of fine river-borne particle inputs in the surface layer during the December flood contributed to the persistence of the suspended sediment stock. 
The off-shelf export of particulate matter during the early December storm and flood events and the following 4-week long relaxation period reached $\sim 3.8 \mathrm{Mt}$. This amount represents $35 \%$ of the maximum amount of suspended particulate matter resulting from both resuspension of the seabed and river input during the 12-h storm. Export was concentrated in the surface layers (first $300 \mathrm{~m}$ ) because of the stratification of the water column (Fig. 7b). The export during the late February event (3 days) amounted to $\sim 2.4 \mathrm{Mt}$, and was concentrated in the nearbottom layers with the dense water flow (Fig. 7c). This is consistent with the near-bottom observations at the canyon heads (Palanques et al., 2006) showing a significantly higher suspended sediment export during the February event. Export was relatively low during strong continental wind episodes (e.g., $0.5 \mathrm{Mt}$ in early January and early March) and moderate marine wind episodes $(0.3 \mathrm{Mt}$ in mid-March, $0.15 \mathrm{Mt}$ in early April and $0.2 \mathrm{Mt}$ in midApril). It was negligible the rest of the time. At the end of the study period, the cumulative sediment export from the Gulf's shelf amounted to $9.1 \mathrm{Mt}$. Exported particulate matter was mostly composed of fine particles $(36.8 \%$ of clay particles, $37.9 \%$ of fine silt, $12.6 \%$ of coarser silt and $12.6 \%$ of aggregates). Comparison between model results and observations (Section 4.3) suggests that export could be underestimated by the model, especially during the winter storm in the Cap de Creus Canyon.

The November 2003-May 2004 sediment budget on the shelf indicates a deficit of $\sim 3.7 \mathrm{Mt}$, implying a net erosion of the seabed. Fig. 10 shows that erosion was not homogeneously distributed, and was primarily localized on the inner and outer shelves. These results are consistent with the grain size distribution of shelf sediments (Fig. 1) and could explain the observed relative paucity of modern sediment on the outer shelf. As previously mentioned, the inner shelf is mainly covered by sandy sediments, and the outer shelf is made up of a mixture of clay particles and

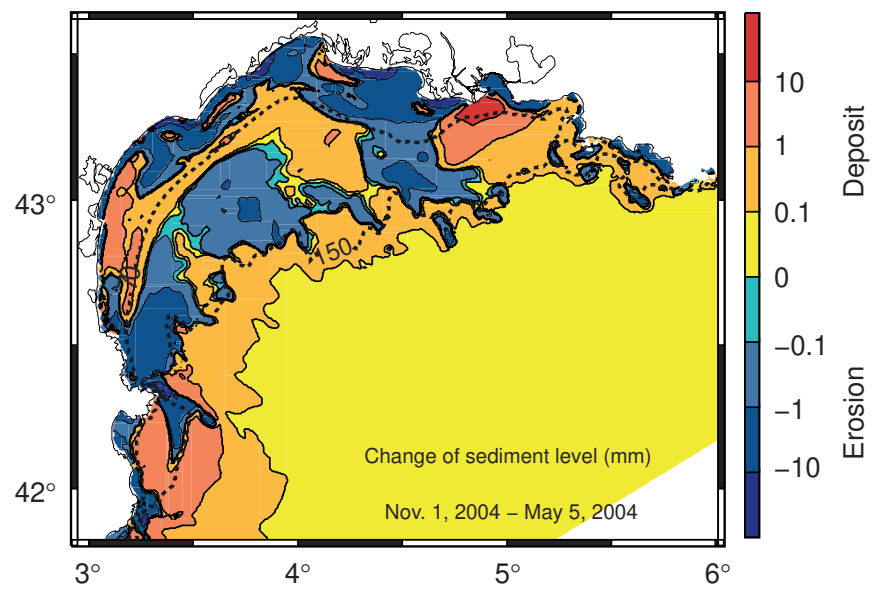

Fig. 10. Change of seabed level $(\mathrm{mm})$ for the entire simulation period (November 1, 2003-May 5, 2004). Positive values represent a net deposit, whilst negative values represent net erosion. 70 and $150 \mathrm{~m}$ isobaths are superimposed as dashed lines. relict sands, thus reflecting energetic conditions. Conversely, the large deposit area between 30 and $80 \mathrm{~m}$ depth on the western half of the shelf partly overlaps the mid-shelf mud belt, reflecting calmer hydrodynamic conditions. Finally, the Rhone prodelta and the deepest part (water depth $>50 \mathrm{~m}$ ) of the eastern shelf, characterized by low waves and current intensities, appear clearly as an area of net deposition. The deposit on the Rhone prodelta $(25 \mathrm{~cm}$ in front of the river mouth) is in agreement with accumulation rates determined by Radakovitch et al. (1999) using radiogenic isotope methods, although the comparison with these measurements is difficult because of the different time scales. In the model, the deposit on the mid-and outer shelf (depth $>50 \mathrm{~m}$ ) is essentially composed of silt and clay. Deposits of sand are visible on the Rhone prodelta and on the inner shelf $(30-40 \mathrm{~m})$. This latter corresponds to sand resuspended during energetic conditions and redeposited a few $\mathrm{km}$ seaward.

\subsubsection{Influence of river inputs}

In order to assess the influence of rivers on the sediment budget and distribution, we performed a simulation by omitting the sediment river inputs. The freshwater discharge was still prescribed. Firstly, the comparison with the reference simulation revealed that the river inputs contributed about $7 \%(\sim 0.6 \mathrm{Mt})$ to the total export. This contribution took place mostly during the relaxation period of the December storm associated with large river floods, when the Rhone turbid plume was transported first alongshore to the Catalan shelf and then along the shelf break due to northern winds. Secondly, as expected, the most visible difference in the sedimentation patterns was located on the Rhone prodelta, where the deposit without river discharges decreased by $\sim 25 \mathrm{~cm}$ in front of the river. The deposits also decreased by more than $1 \mathrm{~cm}$ in front of the Orb, Herault and Aude Rivers. Over the rest of the shelf, the sediment level decreased globally between 0.01 and $1 \mathrm{~mm}$. Therefore, this test indicates that a large part of river inputs was stored on the shelf $(\sim 90 \%)$, mostly on the Rhone prodelta, in agreement with bathymetric data (Maillet et al., 2006).

\subsubsection{Spatial distribution of sediment export}

The shelf edge ( $\sim 200 \mathrm{~m}$ deep) was divided into segments corresponding to the various canyons in order to evaluate the role of submarine canyons in the export of sediment from the shelf to the slope. An additional 4-km segment was defined at the southwestern end of the Gulf of Lions shelf, between the Cap de Creus and the western wall of the canyon. The segments are indicated on the inset of Fig. 9.

During the 6-month simulation, $43 \%$ of the export took place through the southwestern end of the shelf and $42 \%$ in the canyons with a net predominance of the Cap de Creus Canyon ( $41 \%$ of the total export). The rest of the export $(15 \%)$ is distributed along the open slope between canyons $(0.4 \mathrm{Mt}$ in the western region and $0.8 \mathrm{Mt}$ in the central and eastern regions). Thus canyons, with the exception of the 
Table 4

Observed and simulated cumulative cross-isobath fluxes $\left(\mathrm{kg} \mathrm{m}^{-2}\right)$ at the canyon mooring sites.

\begin{tabular}{|c|c|c|c|c|c|c|c|}
\hline & $\begin{array}{l}\text { Cap de Creus } \\
\text { Canyon }\end{array}$ & $\begin{array}{l}\text { Lacaze-Duthiers } \\
\text { Canyon }\end{array}$ & $\begin{array}{l}\text { Aude } \\
\text { Canyon }\end{array}$ & $\begin{array}{l}\text { Herault } \\
\text { Canyon }\end{array}$ & $\begin{array}{l}\text { Petit-Rhone } \\
\text { Canyon }\end{array}$ & $\begin{array}{l}\text { Grand-Rhone } \\
\text { Canyon }\end{array}$ & $\begin{array}{l}\text { Planier } \\
\text { Canyon }\end{array}$ \\
\hline Observations & 3960 & 232 & 114 & 23 & 48 & 156 & 67 \\
\hline Model & 3020 & 610 & 50 & -30 & -40 & 10 & 11 \\
\hline
\end{tabular}

Table 5

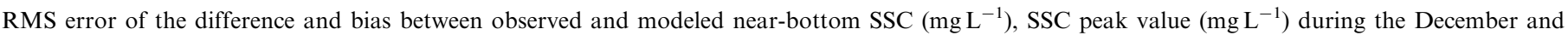

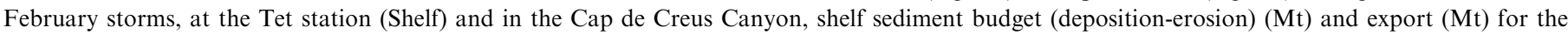
reference and test simulations

\begin{tabular}{|c|c|c|c|c|c|c|c|c|c|c|}
\hline \multirow[t]{2}{*}{$\begin{array}{l}\text { Reference and test } \\
\text { simulations and data }\end{array}$} & \multicolumn{2}{|l|}{ RMS } & \multicolumn{2}{|l|}{ Bias } & \multicolumn{2}{|c|}{$\begin{array}{l}\text { SSC peak in December } \\
2003\end{array}$} & \multicolumn{2}{|c|}{$\begin{array}{l}\text { SSC peak in February } \\
2004\end{array}$} & \multirow{2}{*}{$\begin{array}{l}\text { Sediment } \\
\text { budget } \\
(\mathrm{Mt})\end{array}$} & \multirow[t]{2}{*}{$\begin{array}{l}\text { Export } \\
(\mathrm{Mt})\end{array}$} \\
\hline & $\mathrm{CCC}$ & Shelf & $\mathrm{CCC}$ & Shelf & $\mathrm{CCC}$ & Shelf & $\mathrm{CCC}$ & Shelf & & \\
\hline Reference simulation & 2.45 & 93.7 & -0.76 & 37.09 & 27.4 & 411 & 35 & 116 & -3.7 & 9.1 \\
\hline$\tau_{\mathrm{cri}}=0.1 \mathrm{~N} \mathrm{~m}^{-2}$ & 5.53 & 91.57 & -2.83 & 34.15 & 32.5 & 409 & 56 & 125 & -10.9 & 16.1 \\
\hline$\tau_{\text {cri }}=0.61 \mathrm{Nm}^{-2}$ & 3.16 & 94.27 & 0.48 & 37.80 & 3.0 & 420 & 7.0 & 104 & 1.9 & 3.7 \\
\hline$E_{0}=2 \times 10^{-3} \mathrm{~kg} \mathrm{~m}^{-2} \mathrm{~s}^{-1}$ & 36.57 & 88.09 & -12.68 & 29.57 & 230 & 411 & 305 & 143 & -41.5 & 45.7 \\
\hline$E_{0}=6 \times 10^{-6} \mathrm{~kg} \mathrm{~m}^{-2} \mathrm{~s}^{-1}$ & 2.69 & 95.04 & 0.21 & 38.32 & 7 & 422 & 13 & 98 & 1.0 & 4.5 \\
\hline$\gamma_{0}=1 \times 10^{-3}$ & 2.72 & 78.98 & -1.10 & 16.37 & 27.8 & 1016 & 37 & 252 & -6.1 & 11.3 \\
\hline$\gamma_{0}=1 \times 10^{-5}$ & 2.33 & 107.36 & -0.50 & 46.19 & 27 & 60 & 32 & 35 & -1.3 & 7.0 \\
\hline $\begin{array}{l}\text { Critical clay } \\
\text { content }=3 \%\end{array}$ & 2.42 & 90.03 & -0.79 & 35.16 & 27.4 & 415 & 36 & 124 & -3.5 & 9.0 \\
\hline $\begin{array}{l}\text { Critical clay } \\
\text { content }=14 \%\end{array}$ & 2.68 & 92.78 & -1.05 & 35.37 & 27.7 & 408 & 37.75 & 115 & -4.9 & 10.3 \\
\hline Data & & & & & 32.5 & 470 & 68 & 733 & & \\
\hline
\end{tabular}

Cap de Creus Canyon, did not appear in the model as preferential pathways for the off-shelf export compared to the interfluves. This result has to be carefully considered due to the underestimation by the model of current speed and SSC in central and eastern canyons. We computed the cumulative horizontal sediment flux at the mooring sites using observed and simulated current and SSC (Table 4). These results indicate that even if errors of the model were strong in the central canyons (Herault, Petit-Rhone and Grand-Rhone Canyons), their contribution to the global sediment budget remained low.

The time evolution of the export through the Cap de Creus Canyon and the narrow adjacent shelf is displayed in Fig. 9b. During the early December event, the transport along the shelf was larger than the transport into the canyon. As noted above, this is explained by the large density contrast between shelf and slope waters that limited down-slope transfer during the storm-induced downwelling. Conversely, during the late February storm, the export via the canyon exceeded the alongshore transport because of the cascading of denser shelf water. In early spring, as the water column restratified, the along-shelf transport again became dominant.

\subsubsection{Sensitivity studies}

Due to a lack of information we fixed certain parameters after calibration tests. In this section, we provide an estimate of the error bar on the results associated with the choice of the parameters. We performed a sensitivity analysis by imposing the extreme values of the range found in literature. The impact on comparisons with SSC observations (RMS error, bias and peak values during storms at the shelf site and in the Cap de Creus Canyon), as well as on sediment budget terms (export, sediment budget), is presented in Table 5 .

Imposing a minimum value of $0.1 \mathrm{~N} \mathrm{~m}^{-2}$ for the critical shear stress for cohesive bed resulted in a general overestimation of the observed SSC in the canyon even if peak values during storms are in good agreement with data. The increased erosion obtained for this simulation led to an increase of export and sediment deficit on the shelf by a factor of 2 and 3 , respectively. When a value of $0.61 \mathrm{~N} \mathrm{~m}^{-2}$ was imposed, erosion was strongly reduced. The model represented less than $10 \%$ of the peak values in the Cap de Creus Canyon and at the shelf station during storms, indicating that this simulation was not realistic. If the maximum value of the range found in the literature $\left(2 \times 10^{-3} \mathrm{~kg} \mathrm{~m}^{-2} \mathrm{~s}^{-1}\right)$ was imposed for the erosion parameter $E_{0}$ in the Partheniades (1962) formulation, SSC peaks during storms were highly overestimated, and the RMS error and bias in the canyon were notably higher than in the reference simulation. We also considered that the results of this simulation were not relevant. By imposing the minimum value of the range $\left(6.25 \times 10^{-6} \mathrm{~kg} \mathrm{~m}^{-2} \mathrm{~s}^{-1}\right)$, we 
obtained in the Cap de Creus Canyon peaks smaller by a factor of 4 than in the data. Export was reduced by a factor of 2 and the budget deposition-erosion was positive. Model results were less sensitive to the erosion parameter $\gamma_{0}$ of Smith and McLean (1977) formulation and to the parameter that determines the use of the cohesive or noncohesive formulation for the computation of the resuspension fluxes. Indeed the non-cohesive formulation was applied in a small area close to the coast. By imposing the extreme values of $\gamma_{0}$, export varied between 7.0 and 11.3 $\mathrm{Mt}$ and sediment budget between -6.1 and $-1.3 \mathrm{Mt}$. A variation of the critical clay fraction between $3 \%$ and $14 \%$ produced an export ranging from 9.0 to $10.3 \mathrm{Mt}$ and a sediment budget from -3.5 to $-4.9 \mathrm{Mt}$.

In summary, this analysis demonstrates the high sensitivity of the model to the erosion parameter of the Partheniades (1962) formulation and to the critical shear stress for cohesive bed. We obtained a variation range for export of $10.3 \pm 5.8 \mathrm{Mt}$ and for sediment budget of $-4.95 \pm 5.95 \mathrm{Mt}$, if we did not take into account the results of simulations that show strong differences with observations.

Finally, we performed a simulation where only the noncohesive sediment formulation was applied for erosion flux calculations. In this simulation, SSC was higher than in the reference simulation by a factor of 2.2 in the Cap de Creus Canyon and by a factor of 1.1 at the Tet station where the fraction of fine particles is small in the model. Export reached value of $15 \mathrm{Mt}$ and the deficit in the global sediment budget was $9.8 \mathrm{Mt}$. The critical shear stress in the non-cohesive sediment formulation is smaller than in the cohesive one for fine particles. This explains why resuspension in areas where the fine-grained sediment fraction dominates is more important in this test than in the reference simulation, producing also an increased export. This simulation shows that the budget estimates are sensitive to the erosion flux formulation.

\subsubsection{Interannual variability of export}

Export of suspended sediment from the Gulf of Lions shelf is believed to have a strong interannual variability, related to the intensity of dense shelf water cascading and to the frequency of onshore storms. Sediment trap measurements in the Lacaze-Duthiers Canyon revealed that near-bottom downward particulate fluxes at $1000 \mathrm{~m}$ depth peaked in 1999 (Heussner et al., 2006) and in 2005 (Canals et al., 2006), when very dense shelf water was formed and flushed off the shelf. However these observations only considered the fraction of suspended sediment transported towards intermediate and deep levels of the slope, and are not representative of the export taking place in the surface layer.

Ferré et al. (this issue) estimated, using a similar modeling approach, a sediment budget for the Gulf of Lions for the April 1998-April 1999 period. This period was quite different from the 2003-2004 winter period addressed in the present study, as it was characterized by low river discharges and low eastern to southeastern storm activity, but a massive shelf water export due to very intense dense shelf water formation and cascading. The amount of sediment supplied through rivers and natural resuspension and exported during a comparable time period, from November to March, reveals that exported sediment reached about 6.7 Mt during the 1998-1999 period, and about $10.3 \pm 5.8 \mathrm{Mt}$ during the 2003-2004 period. In both cases, the export of sediment tended to exceed the input by rivers (3.0 Mt in 1998-1999 and $6.9 \pm 1 \mathrm{Mt}$ in 2003-2004). However error bars on export and river inputs estimated for 2003-2004 are quite important. These results suggest a low accumulation or a deficit of the sedimentary budget on the shelf during energetic winter periods. This is not expected to be a longterm phenomenon, since the intense events observed during the 1998-1999 and 2003-2004 winters had moderate to long recurrence periods (from about 5-10 years for intense dense water cascading, 10-50 years for strong marine storms, to 75 years for the Rhone River flood). It is rather believed to represent the upper range of the sediment export off the shelf. Sediment export is indeed believed to be much smaller during calmer years. Lapouyade and Durrieu de Madron (2001) estimated from a box model budgeting approach based on direct measurements performed during two seasonal surveys, an annual export of suspended particulate matter of about $1.9 \mathrm{Mt}$. This export, which is smaller than the contemporaneous river inputs (about 10.9 and $13.8 \mathrm{Mt}$ in 1995 and 1996 respectively, Bourrin et al., 2006), suggests that shelf can be replenished with sediments during hydrodynamically calm years.

\subsubsection{Comparison to other regions}

In the present paper, we estimate the sediment budget of the Gulf of Lions over a short period of time (6 months) affected by energetic wave and current conditions. Comparison of this budget to that of other shelves is difficult because, to our knowledge, previous quantitative studies estimating off-shelf fluxes and deposition-erosion rates on a shelf were performed using sediment core data and estimates of river inputs over secular time scales (Sommerfield and Nittrouer, 1999; Frignani et al., 2005). However, general features of sediment dynamics can be compared for different sites.

First, we found that a large quantity of flood input was stored on the Rhone prodelta, as measured by Maillet et al. (2006). This characteristic was also observed on the Po prodelta (Frignani et al., 2005), using core data. This contrasts with shelves submitted to regular, energetic events (significant tides and wave regime). On the Eel shelf, for example, estimated sediment budgets indicate that a maximum of $\sim 20 \%$ of river fine-grained particles was trapped on the shelf (Sommerfield and Nittrouer, 1999).

Palanques et al. (2002) compared the near-bottom sediment fluxes on the microtidal and low-energy Mediterranean Ebro shelf with that of western USA continental shelves (northern California and Washington shelves) 
submitted to energetic conditions. They reported that on the western USA shelves, sediment resuspension by waves and currents is frequent and reaches the outer shelf, and that the across-shelf and along-shelf fluxes were of the same order of magnitude. On the Ebro shelf, resuspension is mainly produced by waves on the inner shelf during rare storm events. Sediment fluxes on mid- and outer-shelf are one order of magnitude smaller than in the western USA shelves and the along-shelf sediment flux clearly dominates the across-shelf one. Therefore off-shelf transport is expected to be low. The importance of along-shelf transport was also evident on the Adriatic shelf (Frignani et al., 2005). The wave and current conditions encountered on the Gulf of Lions shelf are quite similar to that of the Ebro and Adriatic shelves. Significant amounts of sediment are resuspended on the shelf only during energetic winters. However, in the Adriatic Sea and in the Gulf of Lions, significant across-shelf transport was observed in canyons. The Bari Canyon plays an important role in the off-shelf export of dense water and associated particulate matter in the Adriatic (Turchetto et al., 2007). Despite similar hydrodynamic regimes, the Gulf of Lions is probably a privileged area in the Mediterranean Sea for across-shelf export due to the narrowing of the shelf at its southwestern extremity and to the presence of the Cap de Creus Canyon extending very close to the coast. These characteristics together with the wind-induced cyclonic circulation promote off-shelf export during strong wind events and dense water cascading (Canals et al., 2006). Across-shelf transport (towards the Cap de Creus Canyon) and along-shelf transport (to the adjacent Catalan shelf) were estimated in Section 4.5.3 to be on the same order of magnitude at the southwestern extremity during marine storms.

\section{Conclusions}

A $3 \mathrm{D}$ sediment transport model was validated against data collected on the shelf and slope of the Gulf of Lions during the November 2003-May 2004 EUROSTRATAFORM experiment. This period was characterized by an unusual high occurrence of severe marine storms and floods, and mild dense water cascading activity. The satisfactory agreement between modeling and observations allowed us to investigate the fate of river-borne suspended sediment, the sediment dynamics and transport pathways on the shelf and the export to the slope. Results demonstrate that extreme events (marine storms and floods) controlled most of the sediment transport and budget during the study period.

River inputs, which were mainly supplied by the Rhone River during the December 2003 flood, were predominantly trapped on the prodelta area. About one tenth of the $5.9 \mathrm{Mt}$ supplied by rivers during the 6-month study period was exported off the shelf. Net resuspension of sediment, which occurred mostly during marine storms and reached more than $20 \mathrm{Mt}$ during the study period, contributed to the rest of the particulate matter export. Sediment export was mostly caused by the two major events: the autumnal (December) flooding of rivers and marine storm contributed $\sim 41 \%$ (4-week period) to the total export, while the winter (February) marine storm associated with dense shelf water cascading contributed $\sim 26 \%$ (3-day period) to the total export.

During the December and February storms, erosion was controlled by waves on the inner shelf and by energetic wind-induced bottom currents on the outer shelf. A large portion of resuspended material and river inputs was transported towards the southwestern end of the Gulf by the wind-driven cyclonic circulation. Particulate matter was mostly exported through the narrow Cap de Creus shelf, and also through the nearby canyon due to the storm-induced downwelling process. However, the transition from autumn stratified conditions to winter nonstratified conditions had significant consequences on the sediment transport through canyons. During fall, due to the lower density of shelf water, the downwelling was limited to the upper slope and produced significant deposition of shelf sediments in the canyon heads. Conversely, during wintertime, the downwelling interacted with dense water cascading that enhanced the near-bottom transport of sediment, transporting resuspended sediments towards deeper reaches of the westernmost canyons (Cap de Creus and Lacaze-Duthiers).

\section{Acknowledgements}

This study was supported by the EUROSTRATAFORM Project funded by EU (EVK3-CT-2002-00079), within EU Fifth Framework Programme: Energy, Environment and Sustainable Development. We thank the Captain and crew of $\mathrm{R} / \mathrm{V}$ Tethys II for their help and dedication during the three cruises. We thank Antoni Calafat (UB) and Gilles Saragoni (CEFREM) for their help for the work at sea. We warmly thank Fabrice Ardhuin (SHOM) for the wave model. We are grateful to Serge Berné, Nelly Frumholtz (IFREMER), Sabine Charmasson, Mireille Arnaud (IRSN), Antoine Grémare (LOBB), Vincent Roussiez and François Bourrin (CEFREM), and Didier Sauzade (IFREMER) for the grain size distribution data. We thank Jorge Guillén and Pere Puig (ICM) for their support in observational work. We thank Météo-France for the ALADIN and ARPEGE model outputs. We acknowledge the "Compagnie Nationale du Rhône" for the Rhône discharge, the "Banque HYDRO" for those of the other rivers of the Gulf of Lions and the "Agència Catalana de l'Aigua" for those of Gulf of Rosas, P.-Y. Valantin and C. Tissot from the Service Maritime et de Navigation du Languedoc Roussillon for the wave data. We acknowledge the MFSTEP program for OGCM outputs. We warmly thank computer scientists of Laboratoire d'Aérologie for their assistance. C.U. benefits from a Lavoisier fellowship. 


\section{Appendix A. Erosion fluxes}

For cohesive sediments, we used the law of Partheniades (1962) to calculate the erosion fluxes:

$F^{i}=f_{r}^{i} E_{0}\left(\frac{\tau_{\mathrm{max}, s}}{\tau_{\mathrm{cr}}}-1\right)$ if $\tau_{\mathrm{max}, s} \geqslant \tau_{\mathrm{cr}}$,

where $f_{r}^{i}$ is the fraction of the size class $i$ in the sediment bed. $\tau_{\max , s}$ is the maximal bottom skin friction (see Appendix B). $E_{0}$ and $\tau_{\text {cr }}$ are the erodability of the bed and the critical shear stress, respectively. They are both site-specific parameters. Shaaff et al. (2002) determined the value of $\tau_{\mathrm{cr}}$ to be $0.02 \mathrm{~N} \mathrm{~m}^{-2}$ for removable surficial layer covering muddy bottoms of several sites in the Gulf of Lions. This value is not representative of the more or less consolidated underlying sediment for which literature values vary between 0.1 and $0.61 \mathrm{~N} \mathrm{~m}^{-2}$ (Amos et al., 1997; Harris and Wiberg, 1997; Maa et al., 1998; Zhang et al., 1999; Howing, 1999; Palanques et al., 2002). In the model, $\tau_{\text {cr }}$ was assumed to be $0.2 \mathrm{~N} \mathrm{~m}^{-2}$, which is a typical value for most coastal and estuary areas (Dyer, 1986). $E_{0}$ values are found in the interval $6.25 \times 10^{-6}-2 \times$ $10^{-3} \mathrm{~kg} \mathrm{~m}^{-2} \mathrm{~s}^{-1}$ (Amos et al., 1992b, 1997; Shünemann and Kühl, 1993; Widdows et al., 1998). As we have no information on this parameter, we fixed it at $3 \times 10^{-5} \mathrm{~kg} \mathrm{~m}^{-2} \mathrm{~s}^{-1}$ to fit observations.

The flux of non-cohesive sediments was based on an assumption of equilibrium between the settling of the grains and the diffusion due to turbulent water motion in the bottom layer (Soulsby, 1993). By integrating Eq. (1) over the water column, using an upstream scheme for sedimentation and neglecting advection, one obtains for each grain size:

$\int_{-h}^{0} \frac{\partial C\left(z_{k}\right)}{\partial t} \mathrm{~d} z=-w_{s} C\left(z_{1}\right)+F_{\text {bottom }}$,

where $z_{1}$ is the first grid level above the bed.

Using an assumption of equilibrium, Eq. (A.2) provides our boundary condition:

$F_{\text {bottom }}=-w_{s} C_{\text {equi }}\left(z_{1}\right)$.

Using the hypothesis $F_{\text {bottom }}=-K \partial C / \partial z$ and assuming a parabolic form for the eddy diffusivity near the bottom, the concentration profile is given by the Rouse profile from which $C_{\text {equi }}\left(z_{1}\right)$ can be computed knowing the concentration at a reference level:

$C_{\text {equi }}\left(z_{1}\right)=C_{a}\left(\frac{z_{1}}{z_{a}}\right)^{-b_{\max }}$,

where $b_{\max }=w_{s} / \kappa u_{* \max }, \quad u_{*_{\max }}$ is the maximal shear velocity and $\kappa=0.4$ is the von Karman's constant.

The reference concentration $C_{a}$ at the near-bed elevation $z_{a}$ fixed at $2 \mathrm{D}_{50}$ is given by the formulation of Smith and McLean (1977):

$C_{a}=C_{b} \frac{\gamma_{0} \tau^{\prime}}{1+\gamma_{0} \tau^{\prime}}$, where $C_{b}$, is the concentration of sediment on the bed, fixed at 0.27 due to the lack of information, multiplied by the fraction of the considered grain size, $\tau^{\prime}=\left(\tau_{\max , \mathrm{s}}-\tau_{\mathrm{cr}, \mathrm{nc}}\right) / \tau_{\mathrm{cr}, \mathrm{nc}}$ is the excess shear stress, $\tau_{\mathrm{cr}, n c}$ being the critical shear stress depending of the grain size. $\gamma_{0}$ is the resuspension coefficient. Cited values for $\gamma_{0}$ vary between $10^{-3}$ and $10^{-5}$ in the literature (Drake and Cacchione, 1989). A constant value of $2 \times 10^{-4}$ was used in this implementation.

Eq. (A.4) is valid for $z_{a} \leqslant z_{1} \leqslant z_{w}$ where $z_{w}=u_{* \max } T / 2 \pi$ is the thickness of the wave boundary and $T$ the wave period. When $z_{1}>z_{w}, C_{\text {equi }}\left(z_{1}\right)$ is calculated by first applying the Rouse profile Eq. (A.4) to calculate the sediment concentration at the level $z_{w}$ and then applying the Rouse profile between $z_{w}$ and $z_{1}$ :

$C\left(z_{1}\right)=C\left(z_{w}\right)\left(\frac{z_{1}}{z_{w}}\right)^{-b_{m}}$,

with $b_{m}=w_{s} / \kappa u_{*}$, where $u_{* m}$ is the mean shear velocity.

This method is designed for flat-bed conditions $\left(\tau_{\max , s}>0.8 g\left(\rho_{s}-\rho\right) D_{50}\right)$, so that $\tau_{\max }$ and $\tau_{m}$ are calculated using the grain-related roughness height $\left(z_{0}=D_{50} / 12\right)$. For a rippled bed, the total roughness height (Appendix B) is used for the calculation of the shear stresses in Eqs. (A.4) and (A.6), whereas the grain-related roughness height still be used in Eq. (A.5) providing with the reference concentration. The critical shear stress $\tau_{\mathrm{cr}, n c}$ was computed following Soulsby and Whitehouse (1997) using the median grain size diameter of each size class.

Sensitivity analysis to the choice of the resuspension parameter values is presented in Section 4.5.4.

\section{Appendix B. Bottom shear stress and bed roughness}

The bottom shear stress was deduced from the shear stresses for current-alone conditions $\tau_{c}$ and for wave-alone conditions $\tau_{w}$ using Soulsby et al. (1993) with the parameterization of Fredsøe (1984). The bottom shear stress for current-alone conditions is $\tau_{c}=\rho C_{D} V_{b}^{2}$ where $V_{b}$ is the current velocity at the first grid level $z_{1}, C_{D}=\left[\kappa / \log \left(z_{1} / z_{0}\right)\right]^{2}$ the drag coefficient. The bottom shear stress for wave-alone conditions is $\tau_{w}=\rho f_{w} U_{\text {orb }}^{2}$ where $U_{\text {orb }}=\pi H s / T \sinh (k h)$ is the orbital velocity, $H s$ the significant wave height, $h$ the bathymetry, $k$ the wave number and $f_{w}$ the wave friction factor given by Swart formula (1974):

$f_{w}=0.00251 \exp \left[5.21\left(A / k_{n}\right)^{-0.19}\right]$ for $A / k_{n}>1.57$,

$f_{w}=0.3$ for $A / k_{n} \leqslant 1.57$

$A$ is the orbital excursion length and $k_{n}$ the physical roughness.

The total roughness was considered to be the sum of the grain, bedload and bedform roughness heights (Grant and Madsen, 1982). The grain-related roughness is set to $k_{n}=2.5$ $D_{50}$. The bedload roughness dominating during energetic conditions over sandy beds was computed following: $k_{n}=522 D_{50}\left(\theta_{\mathrm{cws}}-\theta_{\mathrm{cr}}\right)^{0.75}$ where $\theta_{\mathrm{cws}}=\rho u_{* \mathrm{cws}}^{2} /\left(\rho_{s}-\rho\right) g D_{50}$ is the Shields parameter related to the grain roughness, $u *_{\mathrm{cws}}$ 
the combined wave and current shear velocity estimated with the grain-related roughness and $\theta_{\mathrm{cr}}$ the critical shields parameter. For sandy beds, the bedform dimensions (ripple height $\eta_{\text {rip }}$ and spacing $\lambda_{\text {rip }}$ ) were computed following Wiberg and Harris (1994). For silty beds, the roughness is dominated by biological activity. In absence of data reporting the biogenic roughness dimensions in the Gulf of Lions, the spacing was considered to be equal to those measured on a silty site in the northeastern California mid-shelf $\left(\lambda_{\text {bio }}=0.1 \mathrm{~m}\right)$ (Weathcroft, 1994). The height $\eta_{\text {bio }}$ was deduced from the steepness following Harris and Wiberg (1997): $\eta_{\text {bio }} / \lambda_{\text {bio }}=\exp \left(-1.67 \ln T_{*_{w}}-4.11\right)$ where $T_{*_{w}}=\rho u_{*_{w}}^{2} /\left(\rho-\rho_{s}\right) g D_{50}$.

Finally, for mixed sand-mud sediments, the bedform roughness scales (height $\eta_{\text {mix }}$ and spacing $\lambda_{\text {mix }}$ ) were estimated weighting the silt-bed and sand-bed roughness dimensions associated with the corresponding fractions in the sediment bed ( $f r_{s}$ corresponding to the sand fraction):

$\eta_{\text {mix }}=f r_{s} \eta_{\text {rip }}+\left(1-f r_{s}\right) \eta_{\text {bio }}$,

$\lambda_{\text {mix }}=f r_{s} \lambda_{\text {rip }}+\left(1-f r_{s}\right) \lambda_{\text {bio }}$.

The physical roughness was then computed using Grant and Madsen (1982): $k_{n}=27.7 \eta_{\text {rip }}^{2} / \lambda_{\text {rip }}$. The hydraulic roughness height was deduced from Nikuradse (1933): $z_{0}=k_{n} / 30$. Given the small-scale variations generally present at the sea floor, we specified a minimum value of $z_{0}=5 \times 10^{-5} \mathrm{~m}$.

\section{Appendix C. Bed armoring}

The bed armoring process was implemented in the model following Harris and Wiberg (2001). At each grid point, the sediment bed is divided into an uppermost layer called active layer, the only one available for the erosion, and several underlying layers. The thickness of the active layer is defined for sandy and silty beds using different formulations.

For sandy bed, it is related to the depth of the bed that is mixed by migrating ripples (Wiberg et al., 1994):

$\delta_{\text {rip }}=\frac{Q_{b} T}{2 C_{b} \lambda_{\text {rip }}}+6 D_{50}$,

where

$Q_{b}=\sum_{i} f r^{i} \frac{25.3}{\left(\rho_{s}-\rho\right) g}\left(\tau_{\max , s}-\tau_{\mathrm{cr}, n c}^{i}\right)^{1.5}$.

The term $6 D_{50}$ represents the irregularities of the bed surface.

For muddy beds, the depth of the active layer $\delta_{\text {silt }}$ is calculated following Harris and Wiberg (1997):

$\delta_{\text {silt }}=0.006\left(\tau_{\max , s}-\tau_{\operatorname{cr}(50)}\right)+6 D_{50}$.

For mixed sand-mud sediment beds, the thickness of the active layer $\delta_{\text {mix }}$ is considered to be the sum of the sandy and silty active layer depths weighted by the corresponding fractions:

$\delta_{\text {mix }}=f r_{s} \delta_{\text {rip }}+\left(1-f r_{s}\right) \delta_{\text {silt }}$,

where $f r_{s}$ is the sand fraction.
The grain size distribution and thickness of the layers were updated at each time step according to erosion and deposition.

\section{References}

Agrawal, Y.C., Pottsmith, H.C., 2000. Instruments for particle size and settling velocity observations in sediment transport. Marine Geology 168, 89-114.

Amos, C.L., Daborn, G.R., Christian, H.A., Atkinson, A., Robertson, A., 1992b. In situ erosion measurements on fine-grained sediments from the bay of Fundy. Marine Geology 108 (2), 175-196.

Amos, C.L., Feeney, T., Sutherland, T.F., Luternauer, J.L., 1997. The stability of fine-grained sediments from the Fraser River delta. Continental Shelf Research 45, 507-529.

Antonelli, C., Eyrolle, F., Rolland, B., Provansal, M., Sabatier, F., 2008 Suspended sediment and ${ }^{137} \mathrm{Cs}$ fluxes during the exceptional December 2003 flood in the Rhone River, southeast France. Geomorphology 95, 350-360.

Ardhuin, F., Herbers, T.H.C., van Vledder, G.Ph., Watts, K.P., Jensen, R., Graber, H.C., 2007a. Swell and slanting-fetch effects on wind wave growth. Journal of Physical Oceanography 37 (4), 908-931.

Ardhuin, F., Bertotti, L., Bidlot, J.-R., Cavaleri, L., Filipetto, V., Lefevre, J.-M., Wittmann, P., 2007b. Comparison of wind and wave measurements and models in the western Mediterranean Sea. Ocean Engineering 34, 526-541.

Auclair, F., Estournel, C., Marsaleix, P., Pairaud, I., 2006. On coastal ocean embedded modeling. Geophysical Research Letters 33, L14602.

Berlamont, J., Ockenden, M., Toorman, O., Winterwerp, J.C., 1993. The characterization of cohesive sediment properties. Coastal Engineering 21, 105-128.

Blumberg, A.F., Mellor, G., 1987. A description of a three dimensional coastal circulation model. In: Heaps, N. (Ed.), Three dimensional coastal ocean model. American Geophysical Union, 208pp.

Bonnin, J., Heussner, S., Calafat, A., Durrieu de Madron, X., Puig, P., Palanques, A., Canals, M., Avril, J., Delsaut, N. Effect of storms on the spatial and temporal variability of downward particulate fluxes across canyons of the Gulf of Lions (NW Mediterranean). Continental Shelf Research, this issue (in revision).

Bougeault, P., Lacarrère, P., 1989. Parameterization of orographyinduced turbulence in a meso-beta scale model. Monthly Weather Review 117, 1872-1890.

Bourrin, F., Durrieu de Madron, X., Ludwig, W., 2006. Contribution to the study of coastal rivers and associated prodeltas to sediment suplly in the Gulf of Lions. Life and Environment 56 (4), 307-314.

Bourrin, F., Monaco, A., Aloisi, J.-C., Sanchez-Cabeza, J.-A., Lofi, J., Heussner, S., Durrieu de Madron, X., Jeanty, G., Buscail, R., Saragoni, G., 2007. Last millennia sedimentary record on a microtidal, low-accumulation prodelta (Tet NW Mediterranean). Marine Geology 243 (1-4), 77-96.

Canals, M., Puig, P., Durrieu de Madron, X., Heussner, S., Palanques, A., Fabres, J., 2006. Flushing submarine canyons. Nature 444, 354-357.

Curran, K.J., Hill, P.S., Milligan, T.G., Mikkelsen, O.A., Law, B., Durrieu de Madron, X., Bourrin, F., 2007. Settling velocity, effective density, and mass composition of suspended sediment in a coastal bottom boundary layer, Gulf of Lions, France. Continental Shelf Research 27, 1408-1421.

Denamiel, C., 2006. Modélisation hydrodynamique 3D en zone prélittorale: caractérisation des effets des houles de tempête sur la circulation océanique. Ph.D. thesis, University of Montpellier, 424pp.

Drake, D.E., Cacchione, D.C., 1989. Estimates of the suspended reference concentration and resuspension coefficient $\left(\gamma_{0}\right)$ from near bottom observations on the California shelf. Continental Shelf Research 9, 51-64.

Dufau-Julliand, C., Marsaleix, P., Petrenko, A., Dekeyser, I., 2004. 3D Modelling of the Gulf of Lion's hydrodynamics (northwest Mediterranean) during January 1999 (MOOGLI3 Experiment) and late winter 
1999: Western Mediterranean Intermediate Water's (WIW's) formation and cascading over the shelf break. Journal of Geophysical Research 109, C11002.

Dufois, F., Garreau, P., Le Hir, P., Forget, P. Wave- and current-induced bottom shear stress distribution in the Gulf of Lions. Continental Shelf Research, this issue (in revision).

Durrieu de Madron, X., Nyffeler, F., Godet, C.H., 1990. Hydrographic structure and nepheloid spatial distribution. Continental Shelf Research 46, 2003-2027.

Durrieu de Madron, X., Abassi, A., Heussner, S., Monaco, A., Aloisi, J.C., Radakovitch, O., Giresse, P., Buscail, R., Kerherve, P., 2000 Particulate matter and organic carbon budgets for the Gulf of Lions (NW Mediterranean). Oceanologica Acta 23 (6), 717-730.

Durrieu de Madron, X., Ferré, B., Le Corre, G., Grenz, C., Conan, P., Pujo-Pay, M., Buscail, R., Bodiot, O., 2005. Trawling-induced resuspension and dispersal of muddy sediments and dissolved elements in the Gulf of Lions (NW Mediterranean). Continental Shelf Research 25, 2387-2409.

Dyer, K.R., 1986. Coastal and Estuarine Sediment Dynamics. Wiley, Chicherster.

Estournel, C., Kondrachoff, V., Marsaleix, P., Vehil, R., 1997. The plume of the Rhône: numerical simulation and remote sensing. Continental Shelf Research 17, 899-924.

Estournel, C., Durrieu de Madron, X., Marsaleix, P., Auclair, F., Julliand, C., Vehil, R., 2003. Observation and modelisation of the winter coastal oceanic circulation in the Gulf of Lions under wind conditions influenced by the continental orography (FETCH experiment). Journal of Geophysical Research 108 (C3), 1-18.

Estournel, C., Zervakis, V., Marsaleix, P., Papadopoulos, A., Auclair, F., Perivoliotis, L., Tragou, E., 2005. Dense water formation and cascading in the Gulf of Thermaikos (North Aegean) from observations and modelling. Continental Shelf Research 25, 2366-2386.

Ferré, B., Guizien, K., Durrieu de Madron, X., Palanques, A., Guillén, J., Grémare, A., 2005. Fine sediment dynamics study during a winter storm in the Gulf of Lions shelf (NW Mediterranean). Continental Shelf Research 25 (19-20), 2410-2427.

Ferré, B., Durrieu de Madron, X., Estournel, C., Ulses, C., Le Corre, G., 2008. Impact of natural (storm) and anthropogenic (trawl) resuspension on the export of particulate matter to the open ocean. Application to the Gulf of Lions (NW Mediterranean). Continental Shelf Research, doi:10.1016/j.csr.2008.02.002, this issue.

Fredsøe, J., 1984. Turbulent boundary layer in wave-current motion. Journal of Hydraulic Engineering, ASCE 110 (8), 1103-1120.

Frignani, M., Langone, L., Ravaioli, M., Sorgente, D., Alvisi, F., Albertazzi, S., 2005. Fine-sediment mass balance in the western Adriatic continental shelf over a century time scale. Marine Geology 222-223, 113-133.

Garcia-Esteves, J., 2005. Géochimie d'un fleuve côtier méditerranéen : la Têt en Roussillon. Origine et transferts de matières dissoutes et particulaires de la source jusqu'à la mer. Ph.D. Thesis, University of Perpignan, 263pp.

Gardner, W.D., Walsh, I.D., 1990. Distribution of macroaggragates and fine-grained particles across a continent margin and their potential role in fluxes. Deep Sea Research 37, 401-411.

Geernaert, G.L., 1990. Bulk parameterizations for the wind stress and heat fluxes. In: Geenaert, Plant (Eds.), Surface Waves and Fluxes. Current Theory, vol. I. Kluwer Academic Publishers, pp. 91-172.

Grant, W.D., Madsen, O.S., 1982. Movable bed roughness in unsteady oscillatory flow. Journal of Geophysical Research 87, 469-481.

Guillén, J., Palanques, A., Puig, P., Durrieu de Madron, X., Nyffeler, F., 2000. Field calibration of optical sensors for measuring suspended sediment concentration in the western Mediterranean. Scienta Marina 64 (4), 427-435.

Guillén, J., Bourrin, F., Palanques, A., Durrieu de Madron, X., Puig, P., Buscail, R., 2006. Comparison of sediment dynamics during 'wet' and 'dry' storm events on the Tet prodelta. Marine Geology 234, 129-142.

Guizien, K., Brochier, T., Duchêne, J.-C., Koh, B.-S., Marsaleix, P., 2006. Dispersal of owenia fusiformis larvae by wind-driven currents: turbulence, swimming behaviour and mortality in a three-dimensional stochastic model. Marine Ecology Progress Series 311, 47-66.

Harris, C.K., Wiberg, P.L., 1997. Approaches to quantifying long-term continental shelf sediment transport with an exemple from the northern California STRESS mid-shelf site. Continental Shelf Research 11, 1389-1418.

Harris, C.K., Wiberg, P.L., 2001. A two-dimensional, time dependent model of suspended sediment transport and bed reworking for continental shelves. Computers and Geosciences 27, 675-690.

Heussner, S., Durrieu de Madron, X., Calafat, A., Canals, M., Carbonne, J., Delsaut, N., Saragoni, G., 2006. Spatial and temporal variability of downward particle fluxes on a continental slope: lessons from an 8-yr experiment in the Gulf of Lions (NW Mediterranean). Marine Geology 234, 63-92.

Hill, P.S., Syvitski, J.P., Cowan, E.A., Powell, R.H., 1998. In situ observations of floc settling velocities in Glacier Bay, Alaska. Marine Geology 145, 85-94.

Howing, E.J., 1999. Determination of the critical erosion threshold of cohesive sediments on intertidal mud-flats along the Dutch Wadden Sea coast. Estuarine, Coastal and Shelf Science 49, 545-555.

Janssen, P.A.E.M., Hasselmann, K., Hasselmann, S., Komen, G.J., 1994. Parameterization of source terms and the energy balance in a growing wind sea. In: Komen, G.J., et al. (Eds.), Dynamics and Modelling of Ocean Waves. Cambridge University Press, pp. 215-238.

Lapouyade, A., Durrieu de Madron, X., 2001. Seasonal variability of the advective transport of particulate matter and organic carbon in the Gulf of Lions (NW Mediterranean). Oceanologica Acta 24 (3), 295-312.

van Ledden, M., Van Kesteren, W.G.M., Winterwerp, J.C., 2004. A conceptual framework for the erosion behaviour of sand-mud mixtures. Continental Shelf Research 14, 1-11.

Lentz, S.J., Fewings, M., Howd, P., Fredericks, J., Hathaway, K. Observations of undertow over the inner continental shelf. Journal of Physical Oceanography, in revision.

Ludwig, W., Meybeck, M., Abousamra, F., 2003. Riverine transport of water, sediments, and pollutants to the Mediterranean Sea. UNEP MAP Technical Report Series 141, UNEP/MAP Athens, 111pp.

Maa, J.P.-Y., Sanford, L., Halka, J.P., 1998. Sediment resuspension characteristics in Baltimore harbor, Maryland. Marine Geology 146, 137-145.

Maillet, G., Vella, C., Berné, S., Friend, P., Amos, C., Fleury, T.J., Normand, A., 2006. Morphological changes and sedimentary processes induced by the December 2003 flood event at the present mouth of the Grand Rhone River (southern France). Marine Geology 234, 159-177.

Marsaleix, P., Auclair, F., Floor, J.W., Herrmann, M.J., Estournel, C., Pairaud, I., Ulses, C., 2008. Energy conservation issues in sigmacoordinate free surface ocean models. Ocean Modelling 20 (1), 61-89.

Monaco, A., Courp, T., Heussner, S., Carbonne, J., Fowler, S.W., Deniaux, B., 1990. Seasonability and composition of particulate fluxes during ECOMARGE-I, western Gulf of Lions. Continental Shelf Research 10 (9-11), 959-987.

Monaco, A., Durrieu de Madron, X., Radakovitch, O., Heussner, S., Carbonne, J., 1999. Origin and variability of downward biogeochemical fluxes in the Rhone continental margin (NW Mediterranean). Deep-Sea Research Part I 46 (9), 1483-1511.

Nikuradse, J., 1933. Stromungsgesetz in rauhren rohren, vdiforshungshelft (English translation : Laws of flow in rough pipes). Technical Report, NACA Technical Memo 1292. National Advisory Commission for Aeronautics, Washington DC, 62pp.

Ollivier, P., 2006. Interface continent-océan. Géochimie du Rhône (flux et bilan d'érosion) et transfert d'eaux souterraines en Camargue (apports des isotopes du Radium). Ph.D. Thesis, University AixMarseille III, 246pp.

Palanques, A., Puig, P., Guillén, J., Jimenez, J., Gracia, V., SanchezArcilla, A., Madsen, O.S., 2002. Near-bottom suspended sediment fluxes on the macrotidal low-energy Ebro continental shelf (NW Mediterranean). Continental Shelf Research 22, 285-303. 
Palanques, A., Durrieu de Madron, X., Puig, P., Fabres, J., Guillén, J., Calafat, A., Canals, M., Bonnin, J., 2006. Suspended sediment fluxes and transport processes in the Gulf of Lions submarine canyons. The role of storms and dense water cascading. Marine Geology 234, 41-63.

Panagiotopoulos, I., Voulgaris, G., Collins, M.B., 1997. The influence of clay on the threshold of movement on fine sandy beds. Coastal Engineering 32, 19-43.

Parsons, J., Nittrouer, C.A., 2007. Extreme events transporting sediment across continental margins: the relative influence of climate and tectonics. The Sea 13, 681-713.

Partheniades, E., 1962. A study of erosion and deposition of cohesive soils in salt water. Ph.D. Thesis, University of California, Berkeley.

Pethelet-Giraud, E., Negrel, P.-H., Cubizolles, J., 2003. Flux exportés de l'Herault vers la Méditerranée et origine des masses d'eau. Rapport BRGM /RP-52748-FR.

Petrenko, A., Leredde, Y., Marsaleix, P., 2005. Circulation in a stratified and wind-forced Gulf of Lions, NW Mediterranean Sea: in situ and modeling data. Continental Shelf Research 25, 7-27.

Poirel, A., Carrel, G., Olivier, J.M., 2001. Illustration de la complémentarité des chroniques environnementales dans l'étude d'un hydrosystème fluvial : Régime thermique et peuplement piscicoles du Rhône. Workshop on Activities in the Catchement Area and Water Quality, Agence de l'Eau Rhône Mediterranée et Corse, Lyon, France.

Radakovitch, O., Charmasson, S., Arnaud, M., Bouisset, P., 1999. ${ }^{210} \mathrm{~Pb}$ and caesium accumulation in the Rhone delta sediment. Estuarine, Coastal and shelf Science 48, 77-92.

Raudkivi, A.J., 1990. Loose boundary hydraulics, third ed. Pergamon Press, Oxford, UK.

Sempéré, R., Charrière, B., van Wambeke, F., Cauwet, G., 2000. Carbon inputs of the Rhone River to the Mediterranean Sea: biogeochemical implications. Global Biogeochemical Cycles 14 (2), 669-681.

Serrat, P., 1999. Dynamique sédimentaire actuelle d'un système fluvial méditerranéen: l'Agly (France). Sciences de la Terre et des Planètes, Comptes Rendus de l'Académie des Sciences-Series IIA-Earth and Planetary Science 329, 189-196.

Serrat, P., Ludwig, W., Navarro, B., Blazi, J.-L., 2001. Variabilité spatiotemporelle des flux de matières en suspension d'un fleuve côtier méditerranéen: la Tet (France). Science de la Terre et des Planètes, Comptes Rendus de l'Académie des Sciences-Series IIA-Earth and Planetary Science 333, 389-397.

Shaaff, E., Grenz, C., Pinazo, C., 2002. Erosion of particulate inorganic and organic matter in the Gulf of Lions. Comptes Rendus Geoscience 334, 1071-1077.

Sherwood, C.R., Book, J.W., Carniel, S., Cavaleri, L., Chiggiato, J., Das, H., Doyle, J.D., Harris, C.K., Niedoroda, A.W., Perkins, H., Poulain, P.M., Pullen, J., Reed, C.W., Russo, A., Sclavo, M., Signell, R.P., Traykovski, P., Warner, J.C., 2004. Sediment dynamics in the Adriatic sea investigated with coupled models. Oceanography 17 (4), 58-69.

Shünemann, M., Kühl, H., 1993. Experimental investigations of the erosional behaviour of naturally formed mud from the Elbe Estuary and adjacent Wadden Sea, Germany. In: Mehta, A.J. (Ed.), Nearshore and Estuarine Cohesive Sediment Transport, Coastal and Estuarine Studies, vol. 42, pp. 314-330.

Simons, D.B., Sentürk, F. (Eds.), 1977. Sediment Transport Technology, Water and Sediment Dynamics. Water Resources Publication, p. 919.

Smith, J.D., McLean, S.R., 1977. Spatially averaged flow over a wavy surface. Journal of Geophysical Research 82 (12), 1735-1746.
Sommerfield, C.K., Nittrouer, C.A., 1999. Modern accumulation rates and a sediment budget for the Eel shelf: a flood-dominated depositional environment. Marine Geology 154, 227-241.

Soulsby, R.L., 1993. Dynamics of Marine Sands. Thomas Telford Publications, London.

Soulsby, R.L., Whitehouse, R.J.S.W., 1997. Threshold of sediment motion in coastal environments. In: Proceedings of the Pacific Coasts and Ports'97 Conference, Christchurch, University of Canterbury, vol. 1, pp. $149-154$.

Soulsby, R.L., Hamm, L., Klopman, G., Myrhaug, D., Simons, R.R., Thomas, G.P., 1993. Wave-current interaction within and outside the bottom boundary layer. Coastal Engineering 21, 41-69.

Swart, D.H., 1974. Offshore sediment transport and equilibrium beach profiles. Delft Hydraulic Lab Publication, No. 131. Technical Note 151, NOAA/NWS/NCEP/OMB.

Tonani, M., Pinardi, N., Fratianni, C., Dobricic, S., 2007. Forecast and analysis assessment through skill scores. Ocean Science Discussions 4, 189-212.

Tolman, H.L., 1997. User manual and system documentation of Wavewatch-III version 1.15

Turchetto, M., Boldrin, A., Langone, L., Miserocchi, S., Tesi, T., Foglini, F., 2007. Particle transport in the Bari Canyon (southern Adriatic Sea). Marine Geology 246, 231-247.

Ulses, C., Estournel, C., Bonnin, J., Durrieu de Madron, X., Marsaleix, P., 2008. Impact of storms and dense water cascading on shelf-slope exchanges in the Gulf of Lions (NW Mediterranean). Journal of Geophysical Research 113, C02010, doi:10.1029/2006JC003795.

Ulses, C., Estournel, C., Bonnin, J., Durrieu de Madron, X., Marsaleix, P. Impact of storms and dense water cascading on shelf-slope exchanges in the Gulf of Lions (NW Mediterranean). Journal of Geophysical Research, in press.

Vilibić, I., Supić, N., 2005. Dense water generation on a shelf: the case of the Adriatic Sea. Ocean Dynamics 5 (5-6), 403-415.

Weathcroft, R.A., 1994. Temporal variation in bed configuration and onedimensional bottom roughness at the mid-shelf STRESS site Continental Shelf Research 14, 1167-1190.

Weaver, P.P.E., Canals, M., Trincardi, F., 2006. EUROSTRATAFORM Special Issue of Marine Geology editorial. Marine Geology 234 (1-4), $1-2$.

Wentworth, C.K., 1922. A scale of grade and class terms for clastic sediments. Journal of Geology 30, 377-392.

Wiberg, P.L., Harris, C.K., 1994. Ripple geometry in wave dominated environments and symmetric ripples. Journal of Geophysical Research 99 (C4), 775-789.

Wiberg, P.L., Drake, D.E., Cacchione, D.A., 1994. Sediment resuspension and bed armoring during high bottom stress events on the northern California inner continental shelf: measurements and predictions. Continental Shelf Research 14, 1191-1220.

Widdows, J., Brinsley, M.D., Bowley, N., Barrett, C., 1998. A benthic annular flume for in situ measurements of suspension feeding/ biodeposition rates and erosion potential of intertidal cohesive sediments. Estuarine, Coastal and Shelf Science 46, 27-38.

Zanke, U., 1977. Berechnung der Sinkgeschwindigkeiten von Sedimenten. Mitteilungen des Franzius-Institutes 46, 231-245.

Zhang, Y., Swift, D.J., Fan, S., Niedoroda, A.W., Reed, C.W., 1999. Twodimensional numerical modeling of storm deposition of the northern California shelf. Marine Geology 154, 155-168. 